\title{
Effect of Acupuncture on the p38 Signaling Pathway in Several Nervous System Diseases: A Systematic Review
}

\author{
Tzu-Hsuan Wei ${ }^{1}$ and Ching-Liang Hsieh ${ }^{1,2,3, *}$ \\ 1 Department of Chinese Medicine, China Medical University Hospital, Taichung 40447, Taiwan; \\ u102030015@cmu.edu.tw \\ 2 Chinese Medicine Research Center, China Medical University, Taichung 40402, Taiwan \\ 3 Graduate Institute of Acupuncture Science, College of Chinese Medicine, China Medical University, \\ Taichung 40402, Taiwan \\ * Correspondence: clhsieh@mail.cmuh.org.tw
}

Received: 9 June 2020; Accepted: 28 June 2020; Published: 30 June 2020

\begin{abstract}
Acupuncture is clinically used to treat various diseases and exerts positive local and systemic effects in several nervous system diseases. Advanced molecular and clinical studies have continually attempted to decipher the mechanisms underlying these effects of acupuncture. While a growing understanding of the pathophysiology underlying several nervous system diseases shows it to be related to inflammation and impair cell regeneration after ischemic events, the relationship between the therapeutic mechanism of acupuncture and the p38 MAPK signal pathway has yet to be elucidated. This review discusses the latest advancements in the identification of the effect of acupuncture on the p38 signaling pathway in several nervous system diseases. We electronically searched databases including PubMed, Embase, and the Cochrane Library from their inception to April 2020, using the following keywords alone or in various combinations: "acupuncture", "p38 MAPK pathway", "signaling", "stress response", "inflammation", "immune", "pain", "analgesic", "cerebral ischemic injury", "epilepsy", "Alzheimer's disease", "Parkinson's disease", "dementia", "degenerative", and "homeostasis". Manual acupuncture and electroacupuncture confer positive therapeutic effects by regulating proinflammatory cytokines, ion channels, scaffold proteins, and transcription factors including TRPV1/4, $\mathrm{Na}_{\mathrm{v}}, \mathrm{BDNF}$, and NADMR1; consequently, p38 regulates various phenomena including cell communication, remodeling, regeneration, and gene expression. In this review article, we found the most common acupoints for the relief of nervous system disorders including GV20, GV14, ST36, ST37, and LI4. Acupuncture exhibits dual regulatory functions of activating or inhibiting different p38 MAPK pathways, contributing to an overall improvement of clinical symptoms and function in several nervous system diseases.
\end{abstract}

Keywords: acupuncture; p38 signaling pathway; nervous system diseases 


\section{Introduction}

Acupuncture is a form of therapy that has been practiced for more than 3000 years in Asia [1,2]. Medical doctors practice acupuncture under the guidance of meridian theory, which was first recorded in detail in The Yellow Emperor's Classic of Internal Medicine [2]. To perform acupuncture, doctors use thin and sterile metal needles to penetrate specific stimulation points termed acupoints, and they manipulate the needle to achieve "de qi" status [2]. Both manual and electroacupuncture (EA) are used in medical practice. Acupuncture is generally a safe, easy to perform, [3-5] and economical procedure that provides another choice for those who are concerned about the adverse effects of routine managements such as drug prescription [6,7]. Occasional minor problems, such as needles left in patients by mistake, headaches, and drowsiness have been reported after acupuncture treatment; usually, these symptoms are self-resolved after a short rest $[1,3,6,7]$. Due to the limited number of controlled clinical trials that have been published, the efficacy of acupuncture as treatment for has been questioned [8].

Acupuncture is widely used to treat various diseases and exerts positive effects, including analgesia, at both local and systemic levels [3,8-12]; it improves consciousness and cognition [13-20], and it induces therapeutic effects in several nervous system diseases [8,13-20]. Advanced molecular and clinical studies have continually attempted to decipher the mechanisms underlying these effects of acupuncture $[2,7,16,17,20-72]$. The signal transduction pathways through which acupuncture treats nervous system diseases involves multiple signal pathways, including p38 mitogen-activated protein kinases (p38 MAPKs) [7,33-39], Raf/MAPK/extracellular signal-regulated kinases (ERK) 1/2 [27-32,39], Toll-like receptor 4 (TLR4)/ERK [40-43,59], phosphatidylinositol-4,5-bisphosphate 3-kinase (PI3K)/protein kinase B (Akt) [26,31,38,49], adenyl cyclase (AC)/cyclic-adenosine mono-phosphate (cAMP)/protein kinase A (PKA) [25,31,44,47,50-52], apoptosis signal-regulating kinase 1 (ASK1)-c-Jun amino-terminal kinases (JNK)/p38 [7,33-39,44,47,48,63], and downstream cAMP response element-binding protein (CREB), JNK [7,24,54-61,63], mammalian target of rapamycin (mTOR) [26,44-46], nuclear factor kappa-light-chain-enhancer of activated B cells (NF- $\mathrm{kB}$ ) [41-44,47,62], and B-cell lymphoma 2 (Bcl-2)/ Bcl-2 associated X (Bax) balance [57,63-69]. While a growing understanding of the pathophysiology underlying several nervous system diseases shows that it is related to inflammation and the impairment of cell regeneration, the relationship between the therapeutic mechanism of acupuncture and the p38 MAPK signal pathway has yet to be elucidated. A reverse of the detrimental effect of cerebral ischemic or hemorrhagic injury involves the modulation of the ERK/JNK/p38 signal pathway, which leads to anti-apoptosis of the affected brain area. Improvements of Alzheimer's disease, vascular dementia, and Parkinson's disease involves depression or inactivation of the p38 MAPK pathway [32,69-79]. The inactivation of interleukin (IL) $1 \beta$ (IL-1 $\beta$ )/p38 in the frontal lobe and hippocampus has a positive effect on improving cognition and memory. Moreover, acupuncture exerts analgesic effects through the interference of both the ascending and descending pain signaling pathway. These findings continue to shed light on the pivot role of the p38 signaling pathway in several nervous system diseases. The common signal transduction pathways through which acupuncture treats nervous system diseases are summarized in Figure 1. 


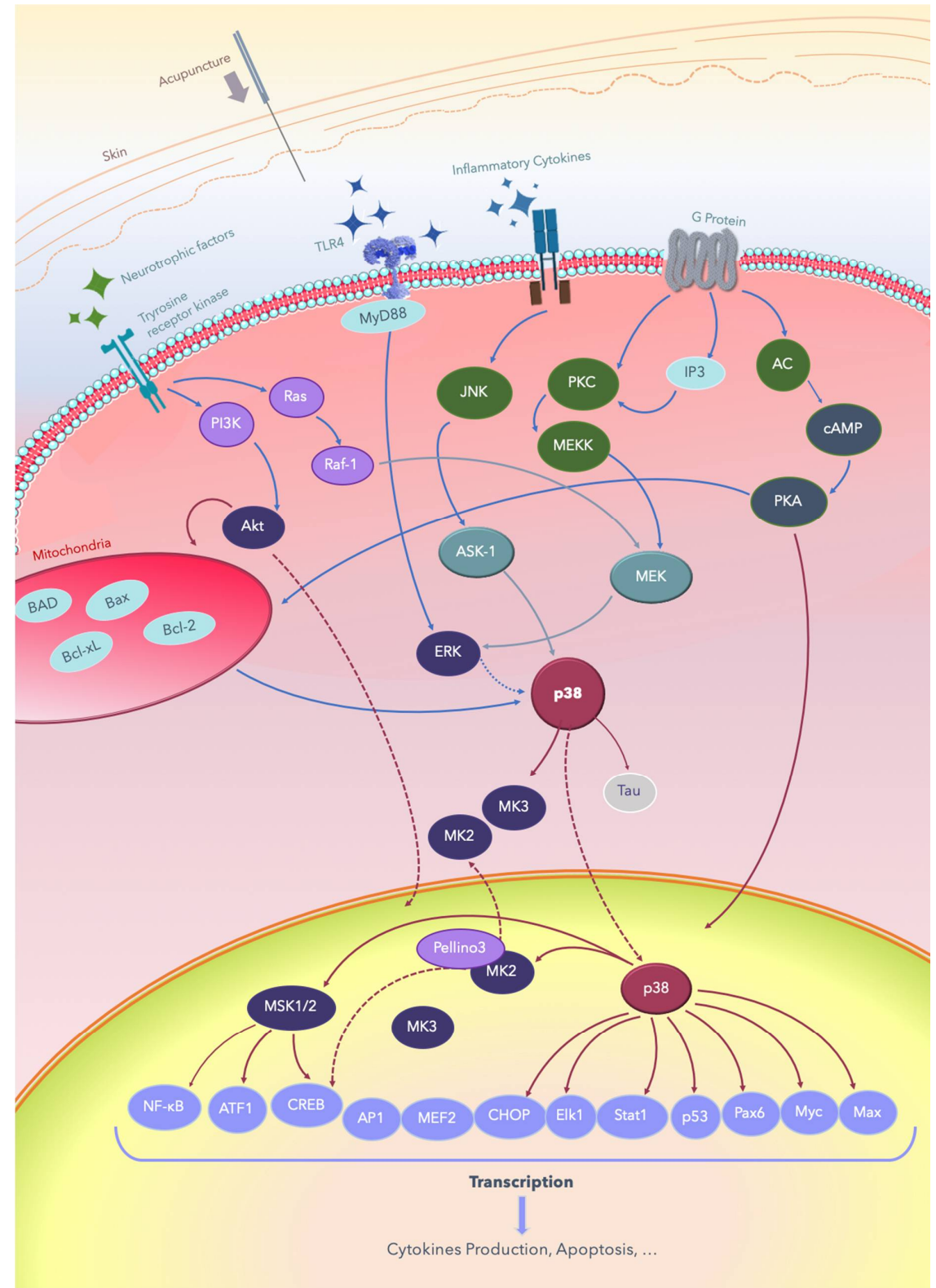

Figure 1. Summary of the signal transduction pathways through which acupuncture treats nervous system diseases. Acupuncture is applied on acupoints and results in de qi, evoking the excitation of cell membrane receptors, such as the Tyrosine receptor kinase and TLR/ligand, and subsequently producing signal transduction. AC: adenyl cyclase; Akt: protein kinase B; AMPK: AMP-activated protein kinase; ASK-1: apoptosis signal-regulating kinase 1; Bad: Bcl-2-associated death promoter; Bax: Bcl-2 associated X; Bcl-2: B-cell lymphoma 2; Bcl2-xl: B-cell lymphomaextralarge; cAMP: cyclic adenosine monophosphate; CREB: cAMP response element-binding protein; ERK: extracellular signal-regulated kinase; IP3: inositol triphosphate; JNK: c-Jun N-terminal kinases; Elk-1: erythroblast transformation specific (ETS) like-1 protein; Max: a transcription factor coded by the myc-associated factor X; MEF: myocyte-enhancing factor; MEK: MEK kinase; MEKK: MK kinase kinase; MSK: mitogenand stress-activated protein kinase; Myc: a group of transcription factors coded by regulator genes and a proto-oncogene called Myc; MyD88: myeloid differentiation primary response 88; TLRs: Toll-like receptors; NF-кB: nuclear factor kappa B; Pax6: a paired-box protein encoded by the master gene Pax-6; PI3K: phosphatidylinositol-4,5-bisphosphate 3-kinase; PKA: protein kinase A; PKC: protein kinase C; ATF: activating transcription factor; AP-1: activator protein; CHOP: C/EBP homologous; Stat1: signal transducer and activator of transcription 1. 


\section{The p38 MAPKs}

MAPKs are a large group of evolutionarily conserved proteins in the plant and animal kingdoms. MAPKs have been implicated in diverse cellular processes including cell survival, proliferation, differentiation, and migration.

Three major subfamilies of MAPK proteins have been defined: ERK, JNK, and the p38 MAPKs (Figure 2). The middle amino acid residue of the conserved Thr-Xxx-Tyr dual-phosphorylation domain (dP-consensus) designates a MAPK protein to its cognate subfamily, and the p38 MAPK subfamily bears the Thr-Gly-Tyr (TGY) dual-phosphorylation domain [77,78].

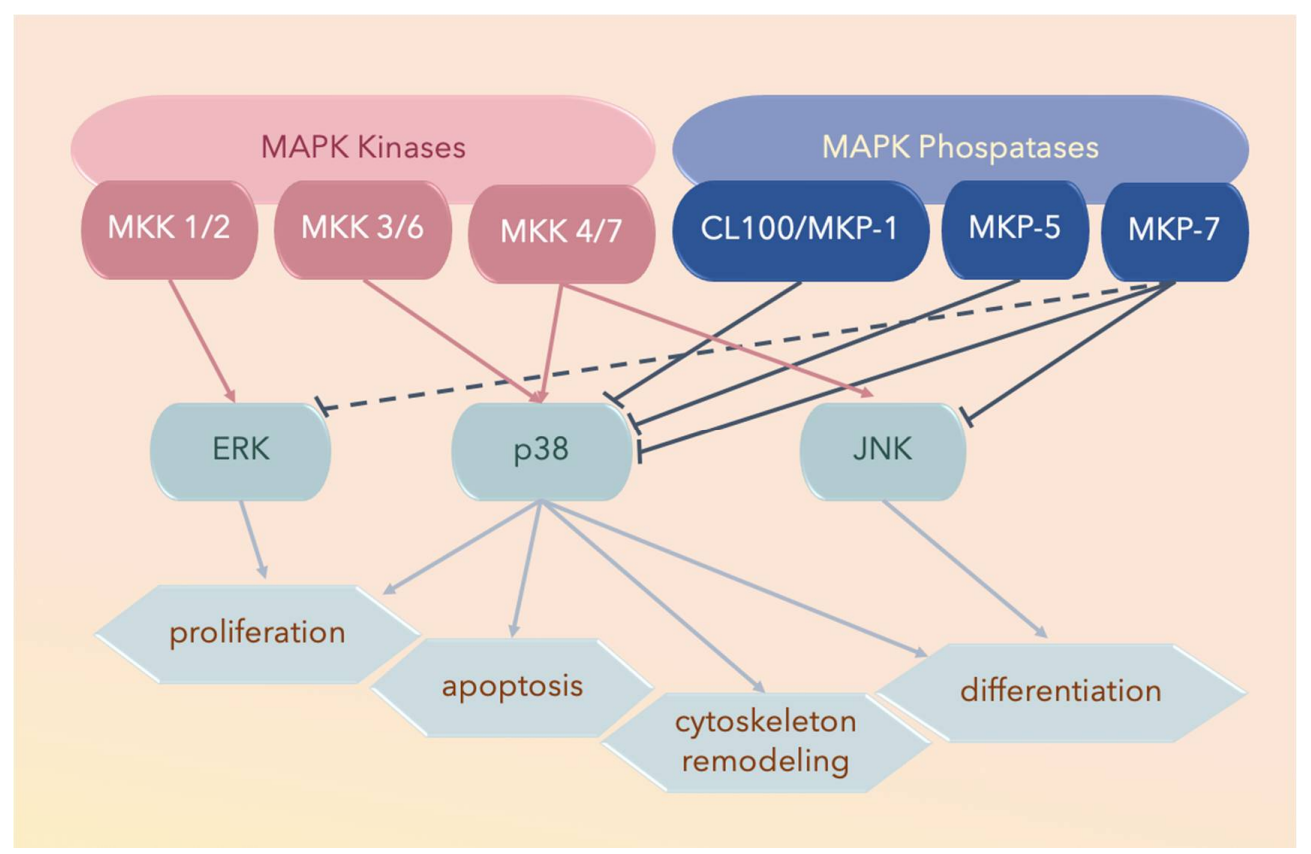

Figure 2. Three major subfamilies of mitogen-activated protein kinases (MAPKs) include extracellular signal-regulated kinases (ERKs), the c-Jun amino-terminal kinases (JNKs), and the p38 MAPKs. The solid lines ending with arrowheads denote activated proteins, solid lines with blunt ends denote deactivated proteins, and the dotted lines with blunt ends denote partially deactivated proteins.

The most extensively studied MAPK pathways are activated by dual-specificity serine-threonine/ tyrosine kinases (STK) termed MAPK kinases (MKKs, MAPKKs, or MAP2Ks), which are activated by MAPKK kinases (MAPKKKs or MAP3Ks). For the p38 MAPK pathway, MKK3 and MKK6 serve as MKKs, and the identified MAPKKKs include MAPKKK2, MAPKKK3, ASK-1, tumor progression locus-2 (Tpl2), and transforming growth factor- $\beta$-activated kinase 1 (TAK-1) of the non-canonical transforming growth factor- $\beta$ (TGF $\beta$ ) pathway. In general, ERK proteins are primarily activated by growth factors; JNKs are activated by stress-, differentiation-, and growth-related factors; and p38 is activated by stress-related factors [78-84].

The p38 MAPK family comprises p38 $\alpha$, p38 $\beta$, p38 $\gamma$, and p38 (summarized in Table 1 ). Considering its central role in developmental programming, cellular adaptation to environmental stress, immune responses, inflammation, tissue regeneration, and tumorigenesis, this protein subfamily has gained increasing attention since its initial discovery. Recent studies using new genetic and pharmacological tools have provided essential information regarding the functions of p38 MAPKs in the pathogenesis of prevalent conditions associated with inflammation, diabetes, neurodegeneration, and cancer [78-99].

The subfamily p38 $\alpha$ is reportedly a homolog of Saccharomyces cerevisiae Hog1, which is an important regulator of osmotic response [77,78,84,100-105]. Other p38 MAPK family members, sharing approximately $60 \%$ sequence similarity with $\mathrm{p} 38 \alpha$, were subsequently cloned and named $\mathrm{p} 38 \beta, \mathrm{p} 38 \gamma$, and p38ס [77,78,84,100-105]. 
Table 1. Members of the p38 mitogen-activated protein kinase (MAPK) subfamily.

\begin{tabular}{|c|c|c|c|c|}
\hline p38 Subfamily & Other Names & Upstream & Location/Function & Dysfunction and Diseases \\
\hline $\mathrm{p} 38 \alpha$ & MAPK14, SAPK2a, CSBP & MKK3, MKK4, MKK6, MKK7 & $\begin{array}{l}\text { Ubiquitously expressed at significant levels in } \\
\text { most cell types. Involved in the regulation of cell } \\
\text { proliferation, differentiation, development, } \\
\text { and response to stress }[77,78,84,99] .\end{array}$ & $\begin{array}{l}\text { Defective placental angiogenesis } \\
\text { causing embryo death (mouse), } \\
\text { symmetric synchronous cell cleavage } \\
\text { (zebrafish), reduction in erythropoietin } \\
\text { (Epo) production [99], leading to } \\
\text { anemia, the impairment of } \\
\text { glucogenesis (mice), and lipid-induced } \\
\text { insulin-resistance (rat) [77,97]. }\end{array}$ \\
\hline $\mathrm{p} 38 \beta$ & MAPK 11 & MKK3, MKK4, MKK6 & $\begin{array}{l}\text { Ubiquitously expressed; upregulated in the CNS } \\
\text { and lungs, downregulated in the } \\
\text { healthy heart [104-106]. }\end{array}$ & No phenotype found [77]. \\
\hline $\mathrm{p} 38 \gamma$ & MAPK 13, ERK6, SAPK3 ${ }^{1}$ & MKK3, MKK4, MKK6MKK7 & $\begin{array}{l}\text { Myoblast and skeletal muscle./ } \\
\text { (1) Under stress conditions, they act on scaffold } \\
\text { proteins targeting the plasma membrane } \\
\text { cytoskeleton at sites of neuromuscular junctions } \\
\text { and gap junctions [107]. } \\
\text { (2) Recent studies indicate that the microbial } \\
\text { metabolite imidazole propionate may contribute } \\
\text { to the pathogenesis of type } 2 \text { diabetes via the } \\
\text { activation of p38 } / \text { p62/mTORC1 [89]. }\end{array}$ & $\begin{array}{l}\text { No phenotype found (mouse) [77]. } \\
\text { Meiotic G2/M progression of oocytes } \\
\text { (xenopus) }[77,104,105] .\end{array}$ \\
\hline p388 & MAPK 12, SAPK4 & MKK3, MKK4, MKK6, MKK7 & $\begin{array}{l}\text { Only expressed in the lungs, kidney, testis, } \\
\text { spleen, pancreas, and small intestine in humans, } \\
\text { rats, and mice, but not in other vertebrates; } \\
\text { enriched in endocrine glands [107,108]./ } \\
\text { (1) Regulates cytoplasmic microtubule dynamics, } \\
\text { including tau protein [107]. } \\
\text { (2) Upregulated in the liver in obese patients } \\
\text { with NAFLD [89]. }\end{array}$ & No phenotype found [77]. \\
\hline
\end{tabular}


X-ray crystallographic studies have yielded structural insights into the mechanisms underlying the interaction between an MAPKK and an MAPK $[103,107]$. Both $p 38 \alpha$ and $p 38 \beta$ are well-conserved at both the gene and protein levels and are important in eliciting innate immunity $[77,78,84,101-105]$. Some p38 $\alpha$ and p38 $\beta$ physiological substrates are summarized in Figure 3; these include transcription factors, transcription factor kinases, cytoskeletal proteins, translational machinery components, and other proteins including metabolic enzymes, glycogen synthase, or cytosolic phospholipase A2 (cPLA2). The p38 $\gamma$ and p38 8 MAPK isoforms can phosphorylate typical 338 MAPK substrates including transcription factors activating transcription factor 2 (ATF2), erythroblast transformation specific (ETS) like-1 protein (Elk-1), or stress-activated protein kinase (SAP1). However, they cannot phosphorylate MK2 or MK3, which are suitable substrates for the other two p38 MAPK isoforms [109-111].

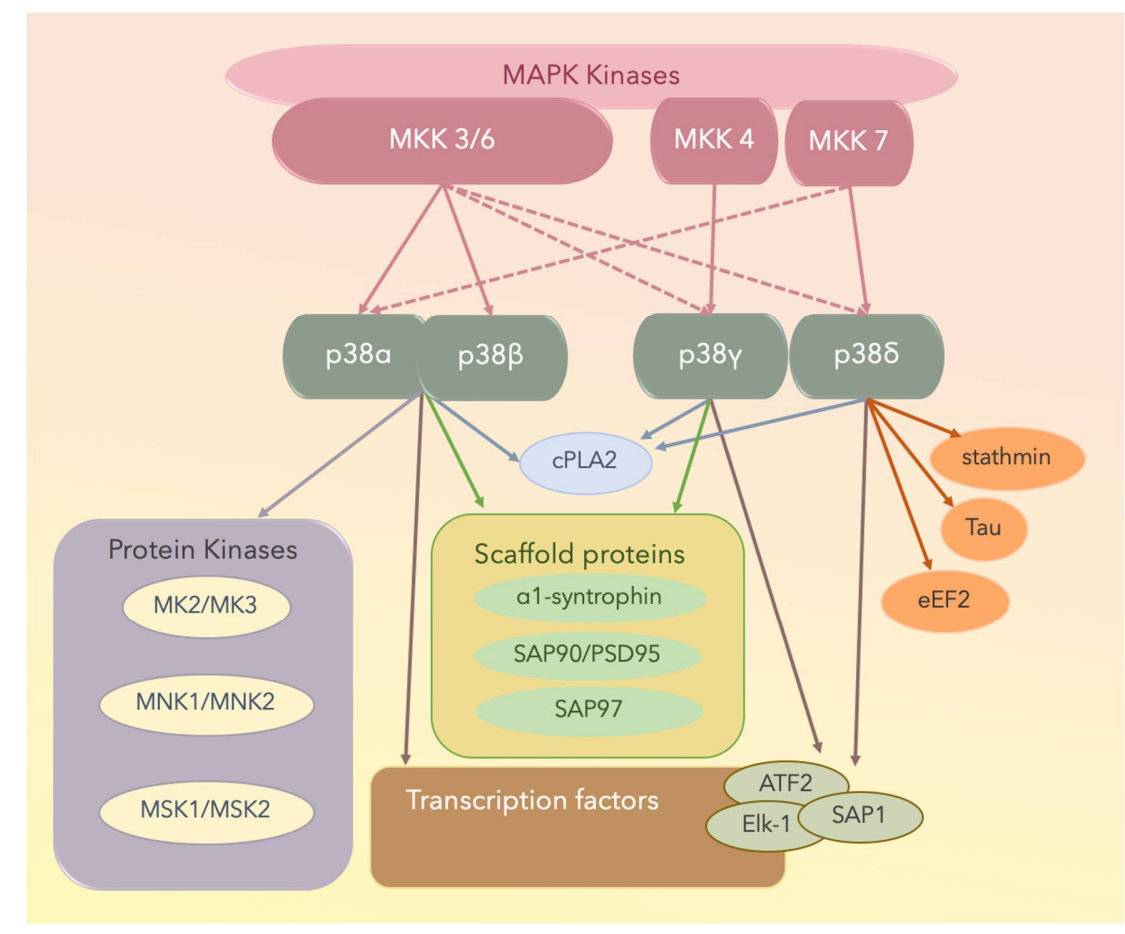

Figure 3. The four p38 MAPK isoforms are p38 $\alpha$, p38 $\beta$, p38 $\gamma$, and p38 8 . Solid lines denote activated proteins, and dotted lines denote partially activated proteins. MNK: mitogen-activated protein kinase-interacting protein; MSK: mitogen- and stress-activated protein kinase; cPLA2: cytosolic phospholipase A2; ATF2: the activating transcription factor 2; Elk-1: the [erythroblast transformation specific (ETS)] like-1 protein; SAP1: stress-activated protein 1; PSD: postsynaptic density proteins; eEF2: eukaryotic elongation factor 2 .

Of the MAPKs, p38 $\gamma$ has a unique short C-terminal sequence, KETXL, which is ideal for binding PDZ domains in proteins, thus accounting for the regulatory role of $\mathrm{p} 38 \gamma$ in the localization of cellular elements and interactions with cytoskeletal components. Under stress conditions, p38 $\gamma$ interacts with and activates various scaffold proteins including $\alpha 1$-syntrophin, SAP90/PSD95, and SAP97, which are generally targeted to the plasma membrane cytoskeleton at specialized sites, including the neuromuscular junction and gap junctions through protein-protein interactions [111].

With respect to $\mathrm{p} 38 \delta$, it potentially contributes to cytoskeletal regulation because it phosphorylates the cytoplasmic protein stathmin [110,111], which is a crucial regulator of microtubule dynamics and the cell cycle, by promoting the depolymerization of microtubules and/or preventing the polymerization of tubulin heterodimers [109,111]. Furthermore, eukaryotic elongation factor 2 (eEF2) kinase and microtubule-associated protein tau are substrates of p38 $[109,111]$. The four p38 isoforms and the substrates are shown in Figure 3. 
These four p38 MAPKs are encoded by different genes and display different histotypic expression patterns, with p38 $\alpha$ being ubiquitously expressed at significant levels in most cell types, whereas the others potentially display more histotypic expression patterns. For example, p38 $\beta$ is expressed in the brain, p38 $\gamma$ is expressed in skeletal muscle (neuromuscular junction, gap junction), and p38 is expressed in endocrine glands [108-115]. The genetic ablation of specific p38 MAPK family members has revealed functional redundancy in this protein subfamily. For example, the osmotic shock-induced phosphorylation of the stress-activated protein 97 (alternatively termed synapse-associated protein 97,

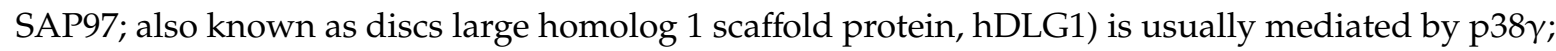
however, in the absence of this kinase, other p38 MAPKs can perform this function.

\section{MAPK Substrates, Signaling Pathways, and Functions}

Nine members of the dual-specificity phosphatases specific for MAPKs, termed MKPs, have been reported. Each member has specific substrates, tissue distribution, and subcellular localization. For example, MAPK phosphatase 7 (MKP-7) binds to and inactivates p38 $\alpha$ and p38 $\beta$ through dephosphorylation; however, it does not interact with p38 $\gamma$ and p388; MKP-5 and CL100/MKP-1 also bind to $\mathrm{p} 38 \alpha$ and p38 $\beta$, but not to p38 $\gamma$ or p38 [115] (Figures 2 and 3).

Several studies have revealed a direct interaction of the N-terminal region of the MAPKK with a docking groove present on the surface of the MAPK distant from the catalytic active site. The second determinant of MAPKK specificity is the structure of the MAPK activation loop harboring the Thr-Xxx-Tyr dual-phosphorylation motif. The specificity of these interactions partly mediates the potential of an individual MAPKK to selectively activate a particular MAPK.

A recent study emphasized that dynamic changes are necessary for enzyme activity [116]. For instance, two MAPKs, ERK2 and p38, are differentially activated owing to differences in dynamism. A comparison of the dynamics of PKA and p38 revealed similarities in their dynamic properties.

\subsection{Dual Phosphorylation by MKKs}

In yeast, only a single MAPKK appears to activate each MAPK, whereas mammalian MAPK signaling modules include more than one MAPKK. The MAPKKs responsible for activating the p38 MAPK pathways appear to be specific to cell type and stimulus [105,107,114,116]. Brancho and Tanaka et al. investigated the mechanism underlying $\mathrm{p} 38$ activation in vivo by examining the effect of disruption of the murine $M k k 3, M k k 4$, and $M k k 6$ genes on the p38 MAPK signaling pathway [100]; they found that Mkk3 and Mkk6 are essential for tumor necrosis factor (TNF)-mediated p38 activation. By contrast, ultraviolet (UV) radiation-induced $\mathrm{p} 38$ activation was mediated by Mkk3, Mkk4, and Mkk6. Furthermore, they reported that the role of Mkk4 in p38 MAPK activation in fibroblasts was largely redundant with those of Mkk3 and Mkk6. Mkk4 is a potentially important p38 MAPK activator in cells with low levels of Mkk3 and Mkk6. These data indicated that p38 MAPK was regulated by the coordinated and selective action of the three different protein kinases MKK3, MKK4, and MKK6 in response to cytokines and exposure to environmental stress. The inactivation of p38 MAPK was reportedly associated with defects in cell cycle arrest and increased tumorigenesis [117-123].

Several MAPKKKs have been implicated in the regulation of p38 MAPK signaling, including the mixed-lineage kinases (MLKs), apoptosis signal-regulating kinase 1 (ASK-1), TAK-1, and some members of the MAPK/ERK kinase kinase (MEKK) family. Low-molecular-weight guanosine-5'-triphosphate (GTP)-binding proteins of the Rho subfamily, including Ras-related C3 botulinum toxin substrate 1 (Rac1), the erythrocyte membrane glycoprotein Cd242, the nonlipid modified Ras-related protein (Rit), the transcription termination factor Rho, and heterotrimeric G-protein-coupled receptors (GPCRs) contribute to p38 activation upstream of MAPKKKs [124-135]. More recently, a new signaling pathway, different from TAK1, that involves the inhibitor of nuclear factor kappa-B kinase (IкBK), NFkB/p105, and Tp12 stimulating MKK3/6, and downstream p38 was established in macrophages [135-139]. The p38 MAPK pathways are shown in Figure 4. 


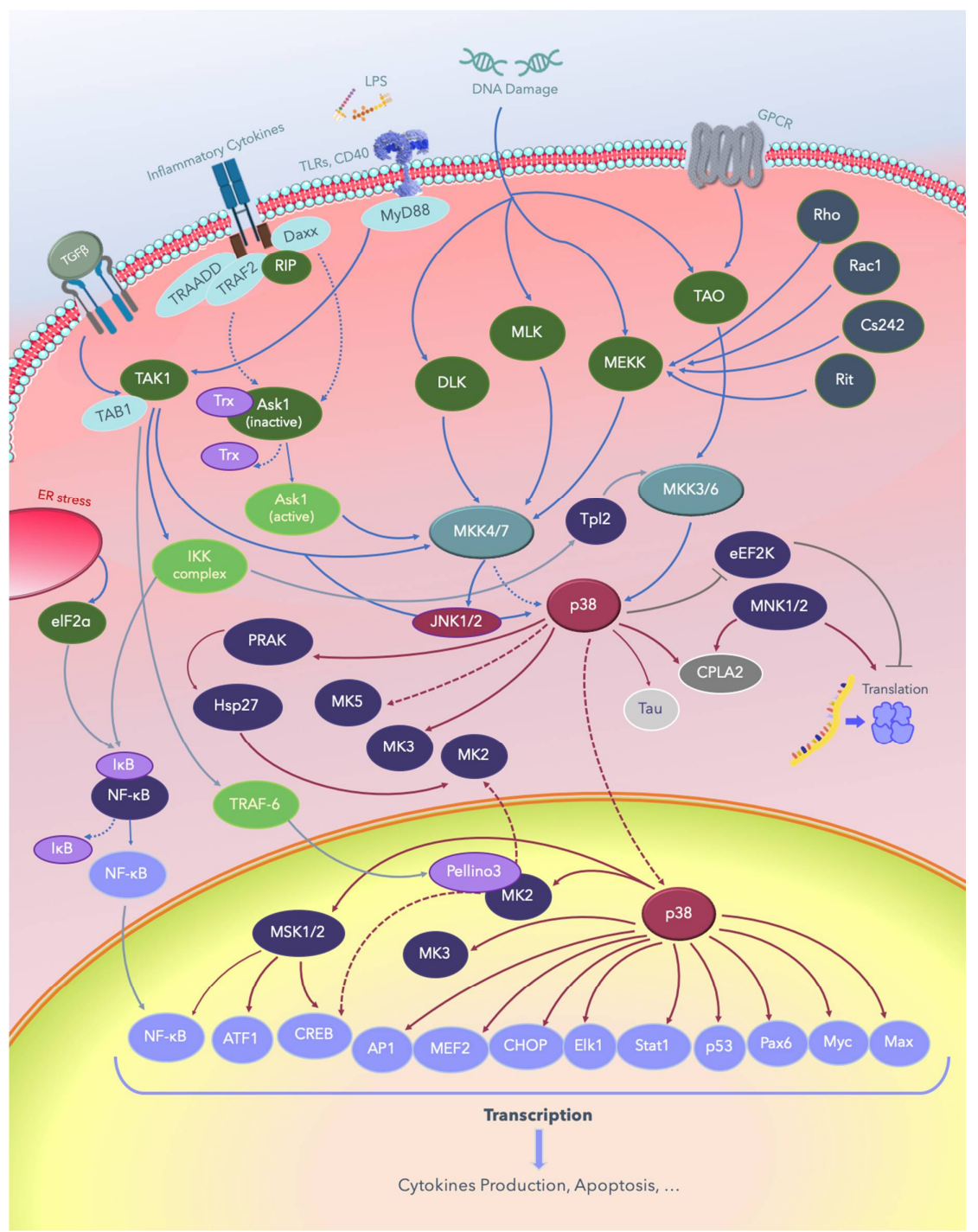

Figure 4. The p38 MAPK signaling pathways. Solid lines indicate signaling pathways and the proteins involved in them; dotted lines indicate the regulatory mechanisms reported in several studies, and lines with blunt ends indicate pathways inhibiting or deactivating downstream substrates. LPS: lipopolysaccharide; TGF $\beta$ : growth factor beta; TLRs: Toll-like receptors; CD40: cluster of differentiation 40 receptors; GPCRs: G-protein-coupled receptors; elF2a: eukaryotic translation initiation factor 2A; ER: endoplasmic reticulum; NF-kB: nuclear factor kappa B; TAB1: TGF-beta-activated kinase1; TRADD: tumor necrosis factor receptor type 1-associated DEATH domain protein; TRAF: tumor necrosis factor receptor (TNFR)-associated factor; Daxx: death domain-associated protein; RIP: receptor-interacting protein kinases; MyD88: myeloid differentiation primary response 88; PRAK: p38-regulated and -activated kinase; Hsp: heat shock proteins; DLK: dual leucine zipper kinase; MLK: mixed-lineage protein kinase; MEKK: MEKK kinase; MEK: MEK kinase; MKK: MK kinase; MNK: mitogen-activated protein kinase-interacting protein; TAO: thousand and one amino acids; eEF2K: eukaryotic elongation factor 2 kinase; cPLA2, cytosolic phospholipase A2; ATF: activating transcription factor; MSK: mitogenand stress-activated protein kinase; CREB: cAMP response element-binding protein; AP-1: activator protein 1; MEF: myocyte enhancing factor; CHOP: C/EBP homologous protein, a member of the CCAAT/enhancer-binding proteins; Elk-1: erythroblast transformation specific (ETS) like-1 protein; Stat1: signal transducer and activator of transcription 1; Pax6: a paired-box protein encoded by the master gene Pax-6; Myc: a group of transcription factors coded by a regulator genes and proto-oncogene called Myc; Max: a transcription factor coded by the myc-associated factor $X$. 


\subsection{Autophosphorylation}

MKK-independent activation is achieved through autophosphorylation and activation of p38 $\alpha$ after interaction with TGF $\beta$-activated kinase 1 (TAB1), which appears to activate $\mathrm{p} 38 \alpha$ via the 5' AMP-activated protein kinase (AMPK) in ischemic heart tissue (Figure 5). TAB1 sequesters p38 $\alpha$ in the cytosol, thus potentially preventing some MKK-activated p38 $\alpha$ functions. However, this mechanism does not contribute to p38 MAPK activation in fibroblasts or epithelial cells under the same conditions [134].

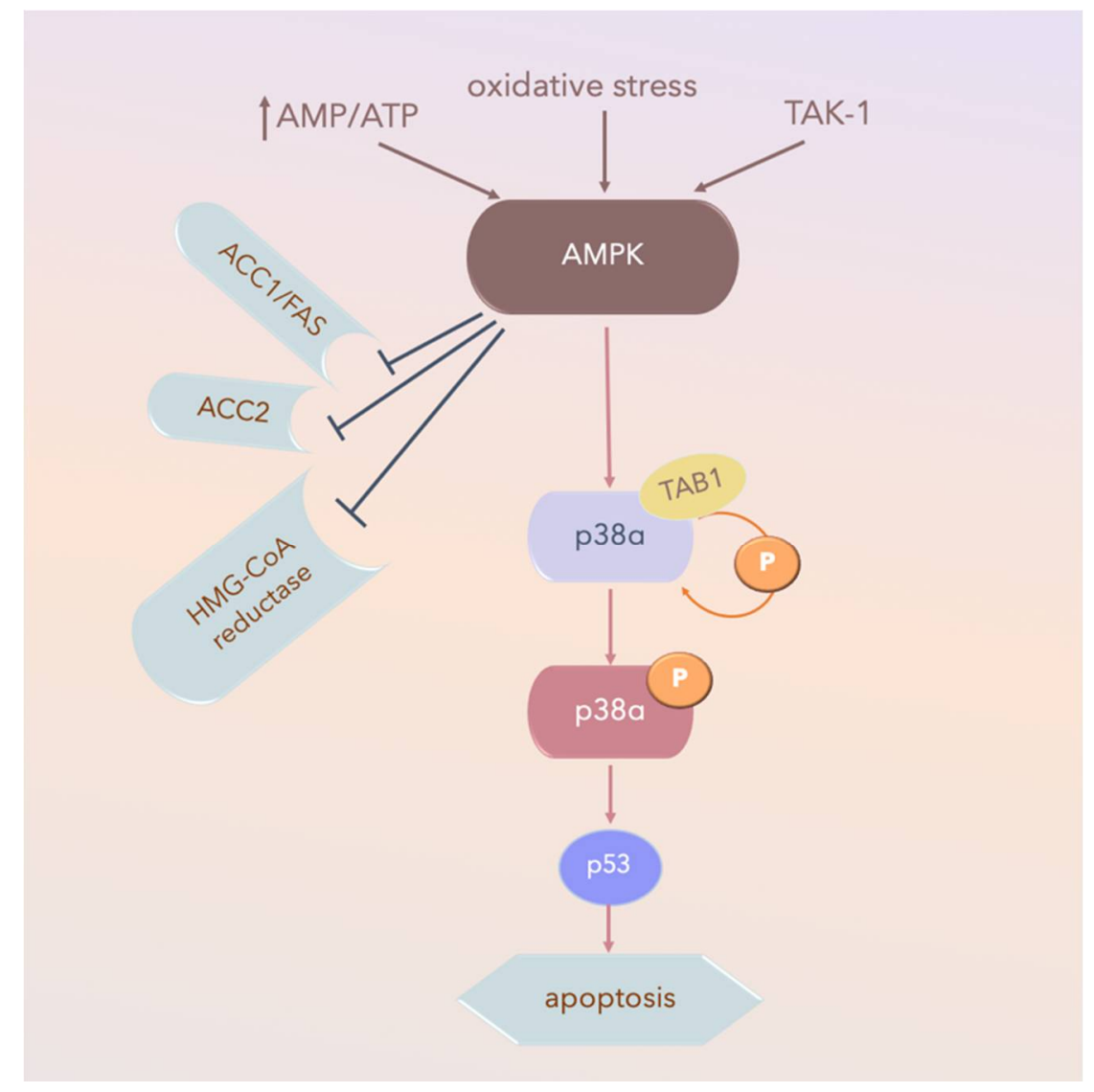

Figure 5. AMPK-activated-p38 $\alpha$ pathways in ischemic heart tissue. Arrow: activated; TAK-1: transforming growth factor- $\beta$-activated kinase 1; AMPK: 5' AMP-activated protein kinase; P: phospho-; AMP: adenosine mono-phosphate; ATP: adenosine tri-phosphate; AMP/ATP: AMP/ATP ratio; ACC1: Acetyl-CoA carboxylase 1; Fas signal pathway, Fas and Fas Ligand (FasL) regulate cell death; HMG-CoA reductase: a rate-controlling enzyme of the mevalonate pathway responsible for cholesterol and other isoprenoid biosynthesis.

Another MKK-independent mechanism underlying p38 $\alpha$ activation has been observed in T-cell stimulation, wherein $\mathrm{p} 38 \alpha$ is activated by T-cell antigen receptor (TCR)-mediated stimulation through p38 $\alpha$ phosphorylation on a noncanonical activating residue, Tyr323. This activated p38 $\alpha$ alters its structural conformation, phosphorylating third-party substrates and its TGY motif [115].

\section{TRPV1 and the p38 Pathway}

Transient receptor potential vanilloid receptors (TRPVs) are mechanosensitive channels highly associated with nervous system functions including pain, memory, and mechanical sensations. Furthermore, capsaicin receptor TRPV1 is a key regulator of pain and inflammation and is upregulated in microglia in the brain, especially in the anterior cingulate cortex [138-140]. The stimulation of microglial TRPV1 induces cortical microglial activation and indirectly enhances glutamatergic neuronal 
transmission by promoting the shedding of extracellular microglial microvesicles (release of vesicles in the extracellular space [141]). Moreover, in the cortex of mice with neuropathic pain, TRPV1 affects the intrinsic electrical properties of neurons and synaptic strength $[142,143]$. This signal transduction can be inhibited by the p38 MAPK inhibitor SB203580. Thus, p38 MAPK is a downstream TRPV1 activator whose phosphorylation plays an essential role in microglial microvesicle shedding by activating P2X purinoceptor 7 (P2X7) ATP receptor [138-143]. Whereas TRPV1 mediates communication between microglia and neurons, inhibition of the phosphorylation of its downstream p38 MAPK inhibits sphingosine metabolism [140-143].

Furthermore, several studies have examined biomarkers of nerve damage, including astrocytic marker glial fibrillary acidic protein (GFAP), microglial marker ionized calcium-binding adapter molecule 1 (Iba-1), S100 calcium-binding protein B (S100B), and the receptor for advanced glycation end-products (RAGE), revealing marked upregulation of these molecules in the dorsal root ganglion (DRG) and spinal cord dorsal horn (SCDH) of Complete Freund's adjuvant (CFA)-treated mice. This inflammatory effect was reversed through electroacupuncture, which achieved an equivalent result to that of TRV1 gene deletion [143].

\section{Brain-Derived Neurotrophic Factor and p38 Pathways}

Microglia cells are resident macrophages in the central nervous system (CNS) with a small soma with thin and branched processes. In the case of neural injury, their processes rapidly migrate toward the site of injury. In peripheral nerve injury, spinal cord microglia are activated. Spinal P2X4 receptors (P2X4Rs), phosphorylated p38 MAPK (p-p38-MAPK), and brain-derived neurotrophic factor (BDNF) are upregulated in spared nerve injury (SNI) rats [144]. BDNF signals to neurons in spinal lamina I and increases intracellular chloride concentration, thereby counteracting gamma-aminobutyric acid (GABA)- and glycine-mediated inhibition in these cells. The disinhibition unmasks innocuous inputs to lamina I neurons and facilitates their responses to noxious inputs [145]. In other studies, BDNF/TrkB was reported to promote inflammation in spinal cord injury through the p38 signaling pathway in the murine model $[40,146]$. Moreover, an upregulation of BDNF expression was observed in rats when applying electroacupuncture (EA) to acupoints GV20 and GV14, which later revealed that EA counteract caspase-3-dependent neuronal apoptosis by activating the Raf-1/MEK1/2/ERK1/2/p90RSK/Bad signaling pathway [147].

These results suggest that increasing the expression of BDNF synthesis, the downregulation of P2X4Rs, and the inhibition of p38 phosphorylation might account for the therapeutic effects induced by acupuncture in nerves injury.

\section{Acupuncture and the Effects of Electric Fields on Nerve Regeneration}

Previous in vitro and a few in vivo studies have reported positive nerve growth-promoting effects of electric fields where the cathode was placed toward the distal end of the injured nerve stumps [148-154]. Chen et al. reported that regenerated nerves in the electrical stimulation group may have a more mature ultrastructure compared with those in the control group [155]. Furthermore, they reported low regeneration success in patients receiving electrical stimulation relative to controls [155].

Together with several previous clinical studies [155-158], these studies show that patients with nerve anastomosis should not receive any electrical stimulation for rehabilitation until their reconnected nerve stumps have grown into a more mature stage of regeneration. One of the mechanisms underlying electroacupuncture (EA) is the relief of acute pain through the release of opiates to activate $\mu-, \delta-$, and $\mathrm{k}$-opioid receptors; furthermore, it can regulate persistent pain by activating $\mu$ - and $\delta$-opioid receptors [25]. These findings explain the application of EA in treating neuropathic pain when pharmacotherapeutic approaches are ineffective.

Furthermore, the analgesic effect of low-frequency $(2 \mathrm{~Hz})$ EA is exerted on the noradrenergic descending pathway, involving the modulation of spinal GABAergic nerves $\left(G_{A B A}\right)$. Administering 
EA at $2 \mathrm{~Hz}$ at acupoint ST36-37 reportedly relieved neuropathic pain through long-term depression (LTD) of the C-fiber [159]. This phenomenon could be blocked by N-methyl-D-aspartate (NMDA) and an opioid receptor antagonist. By contrast, high-frequency $(100 \mathrm{~Hz})$ EA induces long-term potentiation (LTP) of endogenous GABAergic $\left(\mathrm{GABA}_{\mathrm{B}}\right)$ and the serotonergic inhibitory systems through modulation of $\mu$-opioid and 5-hydroxytryptamine 1 (5-HT1) receptors [25,160]. Other studies have reported that delivering EA at acupoints GV14 and GV20 exerts neuroprotective effects by activating CREB, BDNF [161], and $\alpha 7$ nicotinic acetylcholine receptor ( $\alpha 7 \mathrm{nAChR}$ ) [162] while simultaneously reducing S100B-mediated neurotoxicity [163]. Moreover, EA at acupoint ST36 can evoke excitatory signals in either the peripheral nervous system or CNS in vivo [163].

\section{Inflammatory and Neuropathic Pain}

\subsection{Inflammatory Pain}

Protein kinase C (PKC) is rapidly activated by heat or bradykinin and translocates, assisted by scaffolding proteins, from intracellular compartments to the plasma membrane. In rat DRG, the TRPV1 signaling pathways involve the phosphatidylinositol 3-kinases (PI3K), PKC, and calmodulindependent protein kinase II (CaMKII) [143,163]. The p38 $\alpha$ MAPK was first recognized for its role in inflammation where it regulates the biosynthesis of proinflammatory cytokines IL-1 and TNF $\alpha[77,78,98-105,115,164-169]$. After noxious stimulation, activated p38 (phospho-p38) is increased in the spinal cord and DRG neurons and continues to propagate pain signaling by phosphorylating transcription factors and proinflammatory cytokines including TNF- $\alpha$ [168,169]. Inflammation is induced through the activation of these cytokines, followed by their interactions with their cognate receptors and via the small GTPases (e.g., Rac1 and CDC42), leading to p38 activation [169].

\subsection{Neuropathic Pain}

In contrast to physiological pain, pathological pain does not depend on the presence of tissuedamaging stimuli. Neuropathic pain can be agonizing, potentially persisting over long periods, and it is often resistant to known painkillers. Increasing evidence indicates that spinal microglia react and undergo a series of changes that directly influence the establishment of painful peripheral neuropathy [168-170]. After nerve damage, purinergic P2X4 receptors (nonselective cation channels activated by extracellular ATP) are upregulated in spinal microglia in a manner dependent on transcription factors interferon regulatory factor 8 and 5 (IRF8 and IRF5), both of which are expressed in microglia after peripheral nerve injury [171,172]. Furthermore, in spinal microglia, the response to extracellular stimuli results in signal transduction through intracellular signaling cascades involving p38 and ERK. Inhibition of the function or expression of these microglial molecules suppresses the aberrant excitability of dorsal horn neurons and neuropathic pain [172].

Since MAPKs significantly contribute to the development of hyperalgesia, the inhibition of any of the three pathways, namely the ERK, p38, and JNK pathways, can rescue inflammatory or neuropathic pain. Several studies have reported that 2- and $15-\mathrm{Hz}$ EA can downregulate cerebral TRPV4 expression and attenuate chronic constriction injury (CCI)-induced neuropathic pain in an animal model [173-179]. Furthermore, Huang et al. reported that EA modulates both excitatory and inhibitory neurotransmitters to relieve neuropathic pain in the higher brain regions [175]. The hippocampus plays an integral role in the transition from acute to chronic pain in the limbic system by activating NMDA receptors and subsequently prolonging acute nociceptive stimuli that continue activating the descending pathways of pain (Figure 6). 


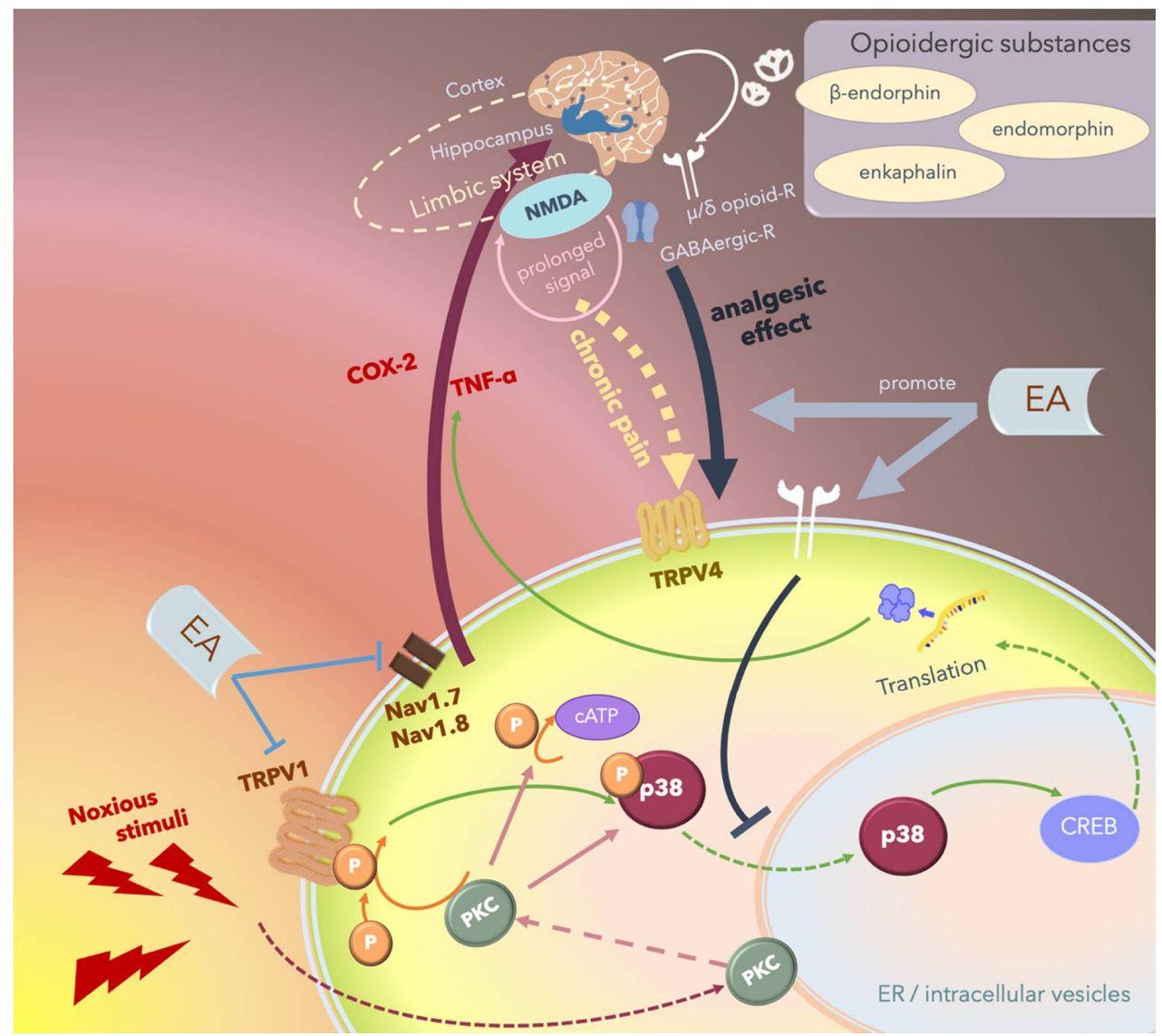

Figure 6. Schematic of the potential mechanism underlying the electroacupuncture (EA)-mediated analgesic effect. Noxious stimuli including heat or proinflammatory cytokines are transduced by the transient receptor potential vanilloid 1 (TRPV1) into the cells, thus phosphorylating and activating p38, which translocates from the cytosol to the nucleus and promotes transcription by affecting cAMP response element-binding protein (CREB), thus upregulating specific proteins including inflammatory cytokines or inducing apoptosis. These noxious stimuli can also directly activate protein kinase $\mathrm{C}$ (PKC). Nociception regulation by TRPV1 and $\mathrm{Na}_{\mathrm{v}} 1.7 / 1.8$ receptor stimulation in the peripheral nerves propagates the signal through the ascending pathway and upregulates proinflammatory cytokines including cyclooxygenase- 2 (COX-2) and tumor necrosis factor- $\alpha$ (TNF $\alpha)$ in the central nervous system, and the signal is then perceived as "pain". Chronic pain re-emerges when nociceptive signals cause prolonged stimulation through hippocampal N-methyl-D-aspartate receptor (NMDA) receptors and some other areas of the limbic system, and the signals are transmitted through the descending pathway, stimulating TRPV4 and triggering pain. Endogenic analgesic mechanisms involve the release of opioidergic substances that bind to $\gamma$-aminobutyric acidergic (GABAergic) receptors and $\mu$-or $\delta$-opioid receptors that act locally in the central nervous system and inhibit the descending pain pathway. EA exerts therapeutic effects by inhibiting the ascending pain pathway and intracellular p38-mediated inflammatory pathway by stimulating peripheral opioid receptors. Furthermore, EA promotes endogenic analgesic mechanisms, thus exerting immediate local analgesic effects and rescuing CNS-induced chronic pain.

\subsection{Post-Operation Pain}

Presurgical sham-, low-, and high-frequency EA treatments were reported to significantly reduce the postoperative patient-controlled analgesia morphine requirement; moreover, both low- and high-frequency EA decreased opioid-related side effects including nausea and dizziness throughout the first postoperative day [176,177]. Among these studies, ST36 and LI4 were the most frequent acupoints manipulated to achieve analgesic effects [summarized in Table 2]. 
Table 2. The effect of acupuncture on inflammatory and neuropathic pain.

\begin{tabular}{|c|c|c|c|c|c|}
\hline Study & Model & Intervention & Acupoints & Evaluation & Result \\
\hline Hsu et al., (2014) [173] & SD rats & $\begin{array}{l}\text { CCI-induced neuropathic pain; } \\
\text { EA, 2- and 15-Hz, } 20 \mathrm{~min}\end{array}$ & $\begin{array}{l}\text { Ipsilateral ST36-ST37 of } \\
\text { the affected limb }\end{array}$ & $\begin{array}{l}\text { Behavioral responses to stimuli; } \\
\text { expression of TRPV1/4 in the cerebral } \\
\text { cortex and lumbar spinal cord }\end{array}$ & $\begin{array}{l}\text { EA relieved neuropathic pain; } \\
\text { downregulation of cerebral } \\
\text { TRPV4 expression. }\end{array}$ \\
\hline Jiang et al., (2018) [174] & SD rats & $\begin{array}{l}\text { CCI-induced neuropathic pain; } \\
\text { EA, 2- and 15-Hz, } 20 \mathrm{~min}\end{array}$ & $\begin{array}{l}\text { Bilateral L4-L6 Hua Tuo } \\
\text { Jia Ji (EX-B2) }\end{array}$ & $\begin{array}{c}\mathrm{GABA}_{\mathrm{A}}, \mathrm{A} 1 \mathrm{R}, \mathrm{TRPV} 1 / 4 \text {, and mGluR3 } \\
\text { in the DRG }\end{array}$ & $\begin{array}{l}\text { EA reduced the pain response, } \\
\text { upregulating the GABA } \text { A }_{A} \\
\text { receptor in the spinal cord. }\end{array}$ \\
\hline Huang et al., (2019) [175] & SD rats & $\begin{array}{l}\text { CCI-induced neuropathic pain; } \\
\text { EA, 2-, 15- and 50-Hz, } 20 \mathrm{~min}\end{array}$ & GV20, GV14 & $\begin{array}{l}\text { Expression of the } \mathrm{GABA}_{\mathrm{A}} \text { receptor } \\
\text { and the level of glutamate in the } \\
\text { hippocampus and periaqueductal } \\
\text { gray (PAG) area. }\end{array}$ & $\begin{array}{l}\text { EA reduced the pain response; } \\
\text { suppressed hippocampal } \\
\text { GABA }_{\mathrm{A}} \text { receptors; decreased } \\
\text { thalamic glutamate levels. }\end{array}$ \\
\hline Lin et al., (2002) [176] & Human & $\begin{array}{l}\text { Preoperative EA, 2- (low) or } \\
\text { 100- (high) Hz, } 20 \mathrm{~min}\end{array}$ & Bilateral ST36 & $\begin{array}{l}\text { Postoperative pain and } \\
\text { opioid-related side effects }\end{array}$ & $\begin{array}{l}\text { Both low- and high-frequency } \\
\text { EA reduced postoperative } \\
\text { analgesic requirements and } \\
\text { associated side effects. }\end{array}$ \\
\hline Wang et al., (1997) [177] & Human & $\begin{array}{l}\text { Postoperative TAES, 2- (low) } \\
\text { or 100- (high) Hz, } 30 \text { min }\end{array}$ & Bilateral LI4 & $\begin{array}{l}\text { Postoperative pain and } \\
\text { opioid-related side effects }\end{array}$ & $\begin{array}{l}\text { Both low- and high-frequency } \\
\text { EA reduced postoperative } \\
\text { analgesic requirements and } \\
\text { associated side effects. }\end{array}$ \\
\hline Chen et al. (2011) [178] & CD1 mice & $\mathrm{EA}, 2-\mathrm{Hz}, 20 \mathrm{~min}$ & Bilateral ST36 & $\begin{array}{l}\text { Behavioral responses in the paw and } \\
\text { ASIC3 overexpression in } \\
\text { DRG neurons. }\end{array}$ & $\begin{array}{c}\text { Rescued mechanical } \\
\text { hyperalgesia and an ASIC3 } \\
\text { downregulation. }\end{array}$ \\
\hline Chen et al. (2012) [179] & ICR mice & $\mathrm{EA}, 2-\mathrm{Hz}, 15 \mathrm{~min}$ & Bilateral ST36 & $\begin{array}{l}\text { Behavioral responses in the paw and } \\
\text { TRPV1/4 overexpression in } \\
\text { DRG neurons. }\end{array}$ & $\begin{array}{l}\text { TRPV1 and TRPV4 } \\
\text { upregulation in DRG neurons } \\
\text { was attenuated by EA. }\end{array}$ \\
\hline Huang et al. (2013) [180] & ICR mice & $\mathrm{EA}, 2-\mathrm{Hz}, 15 \mathrm{~min}$ & Bilateral ST36 & $\begin{array}{l}\text { Behavioral responses in the paw and } \\
\text { the overexpression of } \mathrm{Na}_{\mathrm{v}} 1 \text { in } \\
\text { DRG neurons. }\end{array}$ & $\begin{array}{c}\text { EA attenuated inflammatory } \\
\text { pain by suppressing } \\
\mathrm{Na}_{\mathrm{v}} 1 \text { overexpression. }\end{array}$ \\
\hline Wu et al. (2014) [181] & ICR mice & $\mathrm{MA}, 60 \mathrm{~min}$ & $\begin{array}{l}\text { Ipsilateral ST36 of the } \\
\text { inflamed limb }\end{array}$ & $\begin{array}{l}\text { Behavioral responses in paw; } \\
\text { the overexpression of TRPV1/4, } \\
\text { ASIC3, and CWP components in the } \\
\text { anatomical layers of ST36. }\end{array}$ & $\begin{array}{l}\text { MA induced analgesia, with } \\
\text { high TRPV1 and CWP } \\
\text { overexpression at ST36 } \\
\text { upon MA. }\end{array}$ \\
\hline
\end{tabular}


Table 2. Cont

\begin{tabular}{|c|c|c|c|c|c|}
\hline Study & Model & Intervention & Acupoints & Evaluation & Result \\
\hline Lu et al. (2016) [182] & C57/B6 mice & $\mathrm{EA}, 2-\mathrm{Hz}, 15 \mathrm{~min}$ & $\begin{array}{c}\text { Ipsilateral and } \\
\text { contralateral ST36-ST37 of } \\
\text { the inflamed limb }\end{array}$ & $\begin{array}{l}\text { Behavioral responses in the paw; } \\
\mathrm{Na}_{\mathrm{v}} \text { and TRPV1 overexpression in } \\
\text { DRG neurons. }\end{array}$ & $\begin{array}{l}\text { Hyperalgesia was suppressed } \\
\text { through ipsilateral and } \\
\text { contralateral EA. } \mathrm{Na}_{\mathrm{V}} \text { and } \\
\text { TRPV1 were suppressed } \\
\text { through EA. }\end{array}$ \\
\hline Liao et al. (2017) [143] & C57/B6 mice & $\mathrm{EA}, 2-\mathrm{Hz}, 15 \mathrm{~min}$ & Bilateral ST36 & $\begin{array}{l}\text { Behavioral responses in the paw and } \\
\text { the expression of } \mathrm{Na}_{\mathrm{v}} \text {, GFAP, Iba- } 1 \text {, } \\
\text { S100B, RAGE, and TRPV1 in } \\
\text { DRG neurons. }\end{array}$ & $\begin{array}{c}\text { EA attenuated inflammatory } \\
\text { pain by suppressing Nav1.8 } \\
\text { through S100B, TRPV1, } \\
\text { opioid, and adenosine } \\
\text { pathways. }\end{array}$ \\
\hline Liao et al. (2017) [183] & C57/B6 mice & $\mathrm{EA}, 2-\mathrm{Hz}, 15 \mathrm{~min}$ & Bilateral ST36 & $\begin{array}{l}\text { Behavioral responses in the paw and } \\
\text { the expression of GFAP, S100B, } \\
\text { RAGE, PKC } \varepsilon, E R K, N F-k B, \\
\text { and COX-2 in DRG neurons. }\end{array}$ & $\begin{array}{l}\text { EA attenuated inflammatory } \\
\text { pain by suppressing opioid } \\
\text { and adenosine pathways. }\end{array}$ \\
\hline Yang et al. (2017) [184] & C57/B6 mice & $\mathrm{EA}, 2-\mathrm{Hz}, 15 \mathrm{~min}$ & Bilateral ST36 & $\begin{array}{l}\text { Behavioral responses in the paw and } \\
\text { the expression of TRPV1, PKA, PKC, } \\
\text { PI3K, ERK1/2, p38, JNK, Akt, mTOR, } \\
\text { CREB, NF-KB, Na } 1.7 / 1.8 \text {, GFAP, } \\
\text { S100B, and RAGE in DRG neurons. }\end{array}$ & $\begin{array}{c}\text { EA significantly reduced } \\
\text { chronic inflammatory pain by } \\
\text { downregulating the TRPV1 } \\
\text { pathway from the peripheral } \\
\text { DRG neurons to the central } \\
\text { spinal cord. }\end{array}$ \\
\hline Yen et al. (2019) [185] & C57/B6 mice & $\mathrm{EA}, 2-\mathrm{Hz}, 15 \mathrm{~min}$ & Bilateral LI4 & $\begin{array}{l}\text { Behavioral responses in the paw and } \\
\text { the expression of TRPV1 and ERK1/2 } \\
\text { in the prefrontal cortex, } \\
\text { the hypothalamus, the PAG area, } \\
\text { and DRG neurons. }\end{array}$ & $\begin{array}{c}\text { Pain alleviation immediately } \\
\text { after EA; the expression of } \\
\text { TRPV1-associated molecules } \\
\text { was attenuated by EA in the } \\
\text { prefrontal cortex, } \\
\text { the hypothalamus, the PAG } \\
\text { area, and DRG. }\end{array}$ \\
\hline Hsu et al. (2019) [186] & C57/B6 mice & $\mathrm{EA}, 2-\mathrm{Hz}, 15 \mathrm{~min}$ & Bilateral ST36 & $\begin{array}{l}\text { Behavioral responses in the paw and } \\
\text { the expression of TLR2, PI3K, ERK1/2, } \\
\text { p38, JNK, Akt, mTOR, CREB, NF- } \mathrm{BB} \text {, } \\
\text { and } \mathrm{Na}_{\mathrm{v}} 1.7 / 1.8 \text { in the thalamus. }\end{array}$ & $\begin{array}{l}\text { EA attenuated inflammatory } \\
\text { pain via TLR2 signaling. }\end{array}$ \\
\hline
\end{tabular}


Table 2. Cont

\begin{tabular}{|c|c|c|c|c|c|}
\hline Study & Model & Intervention & Acupoints & Evaluation & Result \\
\hline Yang et al. (2009) [187] & Patients with CTS & $\begin{array}{l}\text { MA, } 30 \mathrm{~min} / \text { session, } 2 \text { session } \\
\text { a week, } 8 \text { session in total }\end{array}$ & Affected side(s), PC6, PC7 & $\begin{array}{l}\text { Motor and sensory NCS; designed } \\
\text { symptomatic questionnaire. }\end{array}$ & $\begin{array}{l}\text { Short-term acupuncture was } \\
\text { as effective as short-term } \\
\text { low-dose steroid for } \\
\text { mild-to-moderate CTS. }\end{array}$ \\
\hline Yang et al. (2011) [188] & Patients with CTS & $\begin{array}{l}\text { MA, } 30 \mathrm{~min} / \text { session, } 2 \text { session } \\
\text { a week, } 8 \text { session in total }\end{array}$ & Affected side(s), PC6, PC7 & NCS; global symptom score. & $\begin{array}{l}\text { Acupuncture had superior } \\
\text { efficacy to steroid treatment } \\
\text { not only in terms of objective } \\
\text { changes in nerve conduction } \\
\text { but also in terms of subjective } \\
\text { symptom assessment in } \\
\text { long-term follow-up. }\end{array}$ \\
\hline Yang et al. (2011) [189] & $\begin{array}{l}\text { Patients with } \\
\text { chronic migraine } \\
\text { (CM) }\end{array}$ & $\begin{array}{l}\text { MA, } 30 \mathrm{~min} / \text { session, } 2 \text { session } \\
\text { a week, } 24 \text { session in total }\end{array}$ & $\begin{array}{c}\text { Bilateral BL2, GB20, } \\
\text { EX-HN5, EX-HN3 } \\
\text { (acupoints relate to the } \\
\text { trigeminal and cervical } \\
\text { dermatomes) }\end{array}$ & $\begin{array}{l}\text { Changes in headache events, MIDAS } \\
\text { scores, HADS scores, BDI-II scores, } \\
\text { reduction of medication. }\end{array}$ & $\begin{array}{l}\text { Acupuncture was similarly } \\
\text { effective or more effective } \\
\text { than prophylactic drug } \\
\text { treatment with less side } \\
\text { effects in migraine. }\end{array}$ \\
\hline
\end{tabular}

A1R: adenosine A1 receptor; ASIC3: acid-sensing ion channel; BDI-II: Beck Depression Inventory-II; CCI: chronic constriction injury; CWP components: components of calcium wave propagation, including pannexin 1, connexin 43, P2Y1, and P2Y2, which can activate a release of ATP after mechanical stimulation of nonneural cells such as subepithelial fibroblasts, $\mathrm{GABA}_{\mathrm{A}}: \gamma$-aminobutyric acid A; GFAP: glial fibrillary acidic protein, an astrocytic marker; HADS: hospital anxiety and depression scale; Iba-1: ionized calcium-binding adaptor molecule 1, a microglia/macrophage specific protein (marker); MA: manual acupuncture; MIDAS: Migraine Disability Assessment; mGluR3: metabotropic glutamate receptor 3; Na $\mathrm{v}_{\mathrm{V}}$ : voltage-gated sodium channels; NCS: nerve conduction study; RAGE: receptor for advanced glycation end-products; TAES: transcutaneous acupoint electrical stimulation; 100B: calcium-binding protein B. 
Furthermore, overexpression of the voltage-gated sodium channel $\left(\mathrm{Na}_{\mathrm{V}}\right)$, TRPV1, and acid-sensing ion channel 3 (ASIC3) in DRG neurons in response to proinflammatory cytokines is a key component of inflammatory pain [179-192]. Low-frequency (2-Hz) EA at acupoint ST36 can reduce inflammatory pain by attenuating ASIC3 overexpression in peripheral DRG neurons. ASIC3 downregulation potentially prolongs the clinical benefits of EA. Goldman et al. reported that acupuncture stimulates adenosine A1 receptor and induces adenosine release, thus relieving inflammation and neuropathic pain, which was not observed in mice lacking adenosine A1 receptors [193]. These results suggest that the opioid and adenosine pathways potentially contribute to analgesia in both manual acupuncture and EA.

\subsection{Migraine}

Migraine is a complex disorder; each episode begins with prodromes and aura (transient focal neurological symptoms). The origin of recurrent headache accompanied by visual or sensory symptoms is speculated to involve the hypothalamus, brain stem, and cortex. Current theories suggest that migraine is a neurovascular disorder involving cortical spreading depression, neurogenic inflammation, and vasodilation [194,195]. Owing to the disease itself or its genetic underpinnings, the brains of individuals who experience migraine are altered structurally and functionally; these molecular, anatomical, and functional abnormalities provide a neuronal substrate for extreme sensitivity to fluctuations in homeostasis, decreased adaptability, and recurrent headaches [194].

A randomized controlled trial investigated the efficacy and tolerability of acupuncture in comparison with topiramate treatment in chronic migraine prophylaxis. The effectiveness of acupuncture was similar to or greater than that of prophylactic pharmacotherapy, with fewer side effects in migraine [194]. The selected acupoints were bilateral BL2, GB20, EX-HN5, and EX-HN3, which are all associated with the trigeminal and cervical dermatomes. Although different combinations of peripheral effects, spinal/supraspinal mechanisms, and cortical and psychological mechanisms potentially contribute to the clinical effects of acupuncture, several other studies have reported that acupuncture potentially exerts curative effects not only through local analgesia but also through anti-inflammation, neuropeptide regulation, cytoskeleton remodeling, cell repair, and improvement in overall homeostasis.

\subsection{Transcutaneous Electrical Nerve Stimulation Versus EA}

The difference between transcutaneous electrical nerve stimulation (TENS) and EA is that TENS involves the application of the cathode at the affected area rather than at acupoints. Furthermore, TENS is used to reduce mechanical hyperalgesia in knee joint inflammatory pain [196,197], although its effectiveness is only sustained for a short time (several days) $[198,199]$. The analgesic effect of low-frequency TENS and EA can be attenuated using $\mu$-opioid receptor blockers, thus indicating the involvement of peripheral opiate release in the underlying mechanism [196]; furthermore, the blockade of $\beta$-endorphin and corticotropin-releasing factor also reduces EA-induced analgesia.

\subsection{Hypothesis Regarding the Long-Term Effect of Acupuncture}

Although proinflammatory cytokines are regulated at different levels, the role of the p38 $\alpha$ MAPK pathway in posttranscriptional regulation has received increasing attention. Numerous p38 MAPK-regulated mRNAs often contain an adenylate-uridylate-rich element (termed AU-rich element or ARE) in the $3^{\prime}$ untranslated region ( $3^{\prime}$ UTR) $[200,201]$. The regulation of mRNA stability is particularly important for the expression of proteins involved in inflammatory response. These elements target mRNAs for rapid decay. The decay of ARE-containing reporter mRNAs is blocked upon p38 MAPK activation. Numerous ARE-containing endogenous mRNAs of inflammatory proteins are destabilized upon p38 inhibition. Some studies have reported a common mechanism underlying gene regulation via the p38 $\alpha$ MAPK pathway for posttranscriptional regulation by the ARE.

These results are consistent with those of several previous animal and clinical studies reporting that EA improves analgesia during the acute phase posttraumatic healing and pain after major surgery $[176,177]$. Numerous prospective randomized controlled trials on carpal tunnel syndrome 
(CTS) have reported that acupuncture at acupoints PC7 and PC6 is as effective and safe as steroid treatment of mild-to-moderate CTS, both in the acute phase and throughout the 1-year follow-up period $[187,188]$. Based on the analgesic mechanisms of acupuncture and EA, which attenuate the p-p38 signaling pathway, the long-term effect of acupuncture or EA may result from neural modulation through posttranscriptional regulation. The potential mechanism underlying EA-mediated analgesic effects is depicted in Figure 6. The underlying mechanisms and the primary results of these studies are summarized in Table 2.

\section{Cerebral Ischemia}

During a cerebral ischemia (CI) event, hypoxia is induced in the brain, followed by the upregulation of various cytokines and potentially neurotoxic molecules. Nitric oxide reportedly influences cerebral oxygen vasoreactivity during severe hypoxia [202]. Both manual acupuncture and EA can increase cerebral blood flow $[13,14]$. Furthermore, 2- and 15-Hz EA at acupoint ST36 increased cerebral blood fluid (CBF) in rats with and without CI [14]. Per the traditional Chinese medicine theory, the Governor Vessel (or the Governor Meridian) directly communicates with the brain. In a previous study, EA at acupoints GV20 and GV14 before artificial mild cerebral ischemia-reperfusion (I/R) injury in an animal model exerted a neuroprotective effect against reperfusion injury [165]. Another neuroprotective mechanism of EA involves the downregulation of astrocytic S100B, which in turn deactivates p38 MAPK and its downstream substrate NF- $\mathrm{KB}$. These effects subsequently reduce oxidative/nitrative stress and inhibit the TNF- $\alpha$ /tumor necrosis factor receptor type 1-associated DEATH domain protein (TRADD)/ Fas-associated protein with death domain (FADD)/cleaved caspase-8/cleaved caspase-3 apoptotic pathway in the ischemic cortical penumbra after reperfusion [89,201-207]. Both 5- and 25-Hz EA at acupoints GV20 and GV16 effectively downregulated reactive astrocytosis to exert neuroprotective effects against cerebral infarction-induced neuronal apoptosis, probably by activating the p38 MAPK/CREB signaling pathway [203].

Heat shock proteins (Hsp) significantly contribute to cellular regenerative processes in injured tissues because Hsp is upregulated during stem cell differentiation; however, the depletion or inhibition of Hsp70/Hsc70 impairs this process [206]. Hsp27 and Hsp70 reportedly contribute to intracellular protein repair after acute CI [206-211]. The dual phosphorylation of p38 MAPK was increased through early ischemia in an in vitro study wherein Hsp27 served as a terminal substrate of the p38 MAPK cascade. A later study indicated that among the p38 MAPKs, p38 $\gamma$ is the principal isoform responsible for the phosphorylation of HSF1 at Ser326 (S326) in cells (phosphorylation at S326 is a hallmark for HSF1 activation) [212], thus contributing to mitotic progression. A protease-mass spectrometry approach unexpectedly revealed that p38 MAPK also catalyzes the phosphorylation of HSF1 at S303/307, which is a repressive posttranslational modification [212,213]. Hsp70 bound MK2 to regulate MK2-p38MAPK interaction in the stem cells, and the essential regions required for Hsp70-MK2 interaction have been identified [206,209-213]. Taken together, Hsp can regulate cell differentiation by interacting with MK2 to stabilize p38 MAPK.

Another study administered $2 \mathrm{~Hz}$ EA the GV20 and ST36 acupoints in rat models of cerebral I/R injury and observed lowered peak levels of adrenocorticotrophic hormone and HSP70, suggesting that EA may inhibit excessive stress, reduce inflammation, and promote neural repair, thus facilitating healing in ischemic stroke [211]. The mechanisms and main results of the identified articles are summarized in Table 3. 
Table 3. The p38 signaling pathway in cerebral ischemic stroke.

\begin{tabular}{|c|c|c|c|c|c|}
\hline Study & Model & Intervention & Acupoints & Evaluation & Result \\
\hline Bäcker et al., (2003) [13] & Healthy human & $\begin{array}{l}\text { MA; manipulation as either } \\
\text { high frequency }(4-8 \mathrm{~Hz}) \text { and } \\
\text { low amplitude }(\mathrm{Hf}-\mathrm{La}) \text { or low } \\
\text { frequency }(1-2 \mathrm{~Hz}) \text { and high } \\
\text { amplitude (Lf-Ha). }\end{array}$ & Right LI4 & $\begin{array}{l}\text { Cerebral blood flow velocity } \\
\text { (CBFV) in both middle cerebral } \\
\text { arteries, arterial blood pressure } \\
\text { (BP), heart rate (HR). }\end{array}$ & $\begin{array}{l}\text { (1) Lf-Ha stimulation was perceived as } \\
\text { more intense and markedly increased } \\
\text { the CBFV in the right hemisphere; } \\
\text { (2) Hf-La stimulation slightly } \\
\text { decreased BP and HR; (3) Lf-Ha } \\
\text { stimulation induced an initial pressor } \\
\text { response (increase of BP, decrease of } \\
\text { HR) and a more marked long-term } \\
\text { BP reduction. }\end{array}$ \\
\hline Hsieh et al., (2006) [14] & SD rats & $\mathrm{EA}, 2-\mathrm{Hz}, 15 \mathrm{~min}$ & Both ST36 & $\begin{array}{l}\text { The levels of nitric oxide in the } \\
\text { peripheral blood and amounts } \\
\text { of calcitonin gene-related } \\
\text { peptide (CGRP) in the cerebral } \\
\text { cortex and thalamus. } \\
\text { L-N (G)-nitro arginine methyl } \\
\text { ester (L-NAME) was used to } \\
\text { measure the changes in CBF. }\end{array}$ & $\begin{array}{l}\text { Both 2- and } 15-\mathrm{Hz} \text { EA increased CBF in } \\
\text { rats with and without CI. }\end{array}$ \\
\hline Cheng et al. (2014) [147] & SD rats & $\begin{array}{l}\mathrm{EA}, 2-\mathrm{Hz}, 25 \text { min once daily } \\
\text { for } 2 \text { consecutive days. }\end{array}$ & GV20, GV14 & $\begin{array}{l}\text { Cerebral infarct area, caspase-3, } \\
\text { BDNF, pRaf-1, MEK1/2, ERK1/2, } \\
\text { p90RSK, and Bad. }\end{array}$ & $\begin{array}{c}\text { EA significantly reduced the cerebral } \\
\text { infarct area, caspase-3 protein } \\
\text { expression levels, and apoptosis in the } \\
\text { ischemic cortex. BDNF, phospho-Raf-1 } \\
\text { (pRaf-1), phospho-MEK1/2 (pMEK1/2), } \\
\text { phospho-ERK1/2 (pERK1/2), } \\
\text { phospho-90 kDa ribosomal S6 kinase } \\
\text { (pp90RSK), and phospho-Bad (pBad) } \\
\text { were markedly upregulated, } \\
\text { and neuronal nuclear antigen (NeuN) } \\
\text { expression was restored. }\end{array}$ \\
\hline Cheng et al. (2014) [161] & SD rats & $\begin{array}{l}\mathrm{EA}, 2-\mathrm{Hz}, 15 \text { min once daily } \\
\text { for } 6 \text { consecutive days. }\end{array}$ & GV20, GV14 & $\begin{array}{l}\text { Cerebral infarct area, GFAP, } \\
\text { S100B, NF-kB, p50, p38 MAPK, } \\
\text { TNF- } \alpha \text {, and iNOS. }\end{array}$ & $\begin{array}{l}\text { EA significantly reduced the cerebral } \\
\text { infarct area and downregulated } \\
\text { astrocytic S100B expression and } \\
\text { decreased p-p38 NF-kB. }\end{array}$ \\
\hline
\end{tabular}


Table 3. Cont.

\begin{tabular}{|c|c|c|c|c|c|}
\hline Study & Model & Intervention & Acupoints & Evaluation & Result \\
\hline Cheng et al. (2015) [203] & SD rats & $\begin{array}{l}\text { EA, 5- or } 25-\mathrm{Hz}, 30 \text { min once } \\
\text { daily for } 7 \text { consecutive days. }\end{array}$ & GV20, GV16 & $\begin{array}{l}\text { Cerebral infarct area, GFAP, } \\
\text { Bax, Bcl-xL, Smac/DIABLO, } \\
\text { p-p38, and CREB. }\end{array}$ & $\begin{array}{l}\text { Both 5- and 25-Hz EA effectively } \\
\text { downregulated reactive astrocytosis to } \\
\text { exert neuroprotective effects against } \\
\text { cerebral infarction, most likely by } \\
\text { activating the p38 MAPK/CREB } \\
\text { signaling pathway. }\end{array}$ \\
\hline Xu et al. (2014) [208] & SD rats & $\mathrm{EA}, 2-\mathrm{Hz}, 20 \mathrm{~min}$ once a day. & GV20, ST36 & $\begin{array}{l}\text { Hsp70 and TNF- } \alpha \\
\text { peripheral serum. }\end{array}$ & $\begin{array}{l}\text { Lowered peak levels of } \\
\text { adrenocorticotrophic hormone } \\
\text { and Hsp70. }\end{array}$ \\
\hline Kuo et al. (2016) [15] & SD rats & $\begin{array}{l}\text { Electrostimulation, 2-Hz, } \\
20 \text { min once daily for } \\
7 \text { consecutive days. }\end{array}$ & Both ears & $\begin{array}{l}\text { Brain nicotinic } \\
\text { acetylcholine receptors. }\end{array}$ & $\begin{array}{l}\text { Two-hertz ES for ameliorated learning } \\
\text { and memory impairment. }\end{array}$ \\
\hline
\end{tabular}

GFAP: glial fibrillary acidic protein; iNOS: inducible nitric oxide synthase; MA: manual acupuncture; Smac/DIABLO: second mitochondrial-derived activator of caspase/direct inhibitor of apoptosis protein-binding protein with low isoelectric point. 


\section{Epilepsy and Seizure}

Epilepsy is characterized by an abnormal electric discharge of the brain, especially in the hippocampus. Epilepsy is usually associated with neuronal loss, astrocyte proliferation, mossy fiber sprouting, and synaptic reorganization in the hippocampus [40,214-219]. Pharmacological treatment approaches, including those employing Western medicine and Chinese herbal medicine, have been attempted to treat or prevent the harmful effect of seizures. For example, Uncaria rhynchophylla is a herb used in traditional Chinese medicine for epilepsy management; its therapeutic effect was reportedly associated with attenuated mossy fiber sprouting, astrocyte proliferation, S100B protein overexpression, and increased hippocampal neuronal survival [219].

Acupuncture has been applied for clinically managing epilepsy. Previous studies have reported that auricular acupuncture positively influences drug-resistant epilepsy patients, potentially through vagus nerve stimulation, attenuating the hyperactive hippocampus, regulating inflammatory cytokine pathways, protecting the hippocampus from apoptosis, and ameliorating the sprouting of mossy fibers in the hippocampus $[40,218,220,221]$. Several antiepileptic mechanisms have been proposed, including the downregulation of JNK or ERK1/2 and pro-inflammatory factors (IL-1 $\beta$, IL-6, TNF- $\alpha$ ) in the cerebral cortex and hippocampus [216]. Another study suggested that auricular EA and EA at ST36-ST37 achieved therapeutic effects by reducing hippocampal hyperactivity and the transient receptor potential cation channel subfamily A member 1 (TRPA1), PKC $\varepsilon, P K C \alpha$, and pERK1/2 signaling pathways [40]. Moreover, auricular EA with EA at ST36-ST37 exerted long-term (6-week observation in the study) beneficial effects by reducing the anti-inflammatory response in numerous cyclooxygenase- 2 (COX-2) immunoreactive cells and hippocampal COX-2 levels [218].

Acupuncture exerts antiepileptic effects by inducing anatomical changes and changes in neurotransmitter, inflammatory cytokine, and transcription factor levels. Regarding studies to date, the related mechanisms primarily involve the suppression of TRPA1/pERK and TLR4/ERK pathways and activation of the PI3K/Akt pathway. Although some studies have reported the inactivation of the TLR4 pathway, accompanied by a reduction in pCaMKII $\alpha$, pERK, pp38, pJNK, and pNFKB levels [40], the role of p38 and its association with the aforementioned signaling pathways remain unclear. These mechanisms and the primary results of the aforementioned studies are summarized in Table 4.

Table 4. The effect of acupuncture on epileptic seizures.

\begin{tabular}{|c|c|c|c|c|c|}
\hline Study & Model & Intervention & Acupoints & Evaluation & Result \\
\hline Kim et al., (2008) [215] & ICR mice & $\begin{array}{l}\text { MA, } 20 \mathrm{~min} / \mathrm{day} \text {, } \\
\quad \text { for } 2 \text { days }\end{array}$ & Bilateral HT8 & $\begin{array}{l}\text { Hippocampal } \\
\text { expression of c-Fos, } \\
\text { c-Jun, and GAD-67 } \\
\text { (CA1 and CA3 areas). }\end{array}$ & $\begin{array}{l}\text { Reduced severity of } \\
\text { epileptic seizures and } \\
\text { the rate of neuronal } \\
\text { death; downregulation } \\
\text { of c-Fos and c-Jun; } \\
\text { upregulation of GAD-67. }\end{array}$ \\
\hline Kim et al. (2012) [216] & C57BL/6 mice & $\begin{array}{l}\text { MA, } 20 \mathrm{~min} / \mathrm{day}, \\
\quad \text { for } 2 \text { days }\end{array}$ & Bilateral HT8 & $\begin{array}{l}\text { Neuronal survival, } \\
\text { microglial and } \\
\text { astrocyte activation, } \\
\text { and hippocampal } \\
\text { mRNA expression of } \\
\text { IL-1 } \beta \text { and TNF- } \alpha \text {. }\end{array}$ & $\begin{array}{l}\text { Inhibition of } \\
\text { hippocampal cell death } \\
\text { and suppression of } \\
\text { KA-induced } \\
\text { inflammatory events. }\end{array}$ \\
\hline Bae et al. (2013) [217] & C57BL/6 mice & $\begin{array}{l}\text { MA, } 20 \mathrm{~min} / \text { day, } \\
\quad \text { for } 3 \text { days }\end{array}$ & Bilateral HT8 & $\begin{array}{l}\text { Neuronal survival and } \\
\text { hippocampal astrocyte } \\
\text { activation. }\end{array}$ & $\begin{array}{l}\text { Acupuncture altered } \\
\text { hippocampal protein } \\
\text { expression to promote } \\
\text { neuronal survival. }\end{array}$ \\
\hline Liu et al. (2014) [218] & SD rats & $\begin{array}{c}\text { EA, } 2 \mathrm{~Hz} \\
30 \mathrm{~min} / \text { day for } \\
7 \text { consecutive days. }\end{array}$ & $\begin{array}{l}\text { Bilateral } \\
\text { ST-36-ST37 } \\
\text { and ears }\end{array}$ & $\begin{array}{l}\text { Changes in mossy } \\
\text { fibers sprouting in the } \\
\text { hippocampus. }\end{array}$ & $\begin{array}{l}\text { Amelioration of mossy } \\
\text { fibers sprouting in the } \\
\text { hippocampus. }\end{array}$ \\
\hline
\end{tabular}


Table 4. Cont.

\begin{tabular}{|c|c|c|c|c|c|}
\hline Study & Model & Intervention & Acupoints & Evaluation & Result \\
\hline Lin et al., (2014) [220] & SD rats & $\begin{array}{c}\mathrm{EA}, 2 \mathrm{~Hz} \\
20 \mathrm{~min} / \text { day, } \\
3 \text { days/week for } \\
6 \text { weeks }\end{array}$ & $\begin{array}{c}\text { Bilateral ears, } \\
\text { ST36, ST37 }\end{array}$ & $\begin{array}{c}\text { EEG and EMG } \\
\text { changes; hippocampal } \\
\text { TRPA1, TRPV4, PKC } \alpha, \\
\text { PKC } \varepsilon \text {, and pERK1/2 } \\
\text { expression. }\end{array}$ & $\begin{array}{c}\text { EA reduced } \\
\text { hippocampal } \\
\text { hyperactivity } \\
\text { accompanied by } \\
\text { alterations in the TRPA1, } \\
\text { PKC }, \text { PKC } \alpha, \\
\text { and pERK } 1 / 2 \\
\text { signaling pathways. }\end{array}$ \\
\hline Liao et al., (2017) [221] & SD rats & $\begin{array}{c}\mathrm{EA}, 2 \mathrm{~Hz} \\
20 \mathrm{~min} / \text { day, } \\
3 \text { days/week for } \\
6 \text { weeks }\end{array}$ & $\begin{array}{l}\text { Bilateral ears, } \\
\text { ST36, ST37 }\end{array}$ & $\begin{array}{c}\text { EEG and EMG } \\
\text { changes; hippocampal } \\
\text { COX-2 levels. }\end{array}$ & $\begin{array}{l}\text { Attenuated COX-2 and } \\
\text { COX-2 immunoreactive } \\
\text { cells in the hippocampal } \\
\text { CA1 region after } \\
\text { epileptic seizures. }\end{array}$ \\
\hline Liao et al. (2018) [40] & SD rats & $\begin{array}{c}\text { EA, } 2 \mathrm{~Hz}, \\
20 \mathrm{~min} / \text { day, } \\
3 \text { days/week for } \\
6 \text { weeks }\end{array}$ & Bilateral ears & $\begin{array}{l}\text { Brain TLR4, CaMKII } \alpha \text {, } \\
\text { ERK, JNK, and NF-KB } \\
\text { expression. }\end{array}$ & $\begin{array}{l}\text { Auricular EA controlled } \\
\text { epileptic seizures by } \\
\text { regulating the TLR4 } \\
\text { signaling pathway. }\end{array}$ \\
\hline
\end{tabular}

GAD-67: glutamate decarboxylase-67; c-Fos, c-Jun: proto-oncogenes that are expressed within some neurons following depolarization, the two form the AP-1 early response transcription factor that regulates gene expression in response to extracellular stimuli; KA: kainic acid; EEG: electroencephalogram; EMG: electromyogram; PKC: protein kinase C; TRPA1: transient receptor potential cation channel subfamily A member 1; TRPV: transient receptor potential vanilloid receptors; pERK: phosphor-extracellular signal-regulated kinases; COX-2: cyclooxygenase-2; TLR4: Toll-like receptor 4; CaMKII $\alpha$ : calmodulin-dependent protein kinase II alpha.

\section{Motion Sickness}

External noxious stimulation alters intracellular signal transduction pathways in primary afferents, potentially contributing to pain hypersensitivity. This pathway proceeds via TRPVs, especially TRPV1 and TRPV4, leading to the rapid phosphorylation of p38 MAPK in the afferent neurons and the induction of hyperalgesia. Recent studies have revealed that thermal stimulation may not be the only trigger for TRPV activation [222,223]. Kaolin consumption was quantified as a behavioral response of an emetic reflex (pica behavior) in a murine model. A previous study reported that TRPV1 levels were significantly increased upon stimulation of motion sickness, and EA at PC6 acupoints attenuated hypothalamic TRPV1 levels and exerted an antiemetic effect [222]. The acupoint PC6 is well-known for its therapeutic effect, especially in relieving nausea and vomiting. This study revealed that the mechanism underlying the reduction of motion sickness potentially involves the TRPV1 pathway [222].

\section{Degenerative Nerve Diseases}

Microglia, the endogenous macrophages of the CNS, monitor their territory through a constant movement of their elaborated thin processes and responses to local stressors and immune disruptions. Clinical studies and preclinical animal models have implicated the dysregulation and overproduction of proinflammatory cytokines from activated microglia in the CNS as contributors to the pathophysiology of chronic neurodegenerative disorders including Alzheimer's disease [16], Parkinson's disease, and multiple sclerosis and acute neurodegenerative conditions including traumatic brain injury and stroke. The p38 $\alpha$ MAPK pathway helps increase the microglial production of proinflammatory cytokines induced by diverse stressors $[16,17,223]$. These results indicate the feasibility of targeting p38 $\alpha$ MAPK to modulate the production of pro-inflammatory cytokines by the CNS.

Few studies have focused on the effects of androgens on neuroinflammation. Yang et al. investigated the neuroprotective role of androgens (including testosterone and its metabolite dihydrotestosterone, DHT) in lipopolysaccharide (LPS)-induced neuroinflammation, neuronal damage, and behavioral dysfunction [18]. DHT potentially inhibits the LPS-induced release of proinflammatory factors in primary microglia by suppressing the TLR4-mediated NF- $\mathrm{KB}$ and p38 signaling pathways, thus protecting neurons from inflammatory damage induced by activated microglia.

Sodium ferulate is used in traditional Chinese medicine (such as the root of Ligusticum chuanxiong and Angelica sinensis) and is speculated to help treat cardiovascular and cerebrovascular diseases by 
preventing thrombosis. Furthermore, sodium ferulate prevents A $\beta$-induced MKK3/MKK6-p38-Hsp27 signaling and reduces apoptosis in the rat hippocampus [17].

\subsection{Alzheimer's Disease}

The pathological hallmarks of Alzheimer's disease (AD) are the accumulation of extracellular plaques and intracellular neurofibrillary tangles that are composed of filaments of $\beta$-amyloid polymers and the neuronal microtubule-associated protein Tau, respectively. Elevated $\beta$-amyloid levels in an $\mathrm{AD}$ brain are speculated to induce microglial activation and the consequent release of proinflammatory cytokines induced by the $\mathrm{p} 38 \mathrm{MAPK}$ pathway, potentially contributing to AD pathogenesis together with other disorders including neuronal injury, trauma, ischemia, and the accumulation of oxidants associated with brain aging $[16,18,224]$.

Since more than half of the phosphorylation sites in paired helical filament-Tau are serine and threonine residues followed by proline, members of the MAPK family, especially p38 $\alpha$, potentially play an important role in phosphorylating Tau [16]. Considering that aberrantly activated JNK and p38 MAPKs are reportedly associated with cells containing filamentous Tau in some neurodegenerative diseases, these kinases may contribute to Tau hyperphosphorylation. Moreover, the p38 MAPK activator, MKK6, is active in neurodegenerative diseases, indicating a potential contribution to Tau hyperphosphorylation in these diseases. Recent studies have reported that Tau is a suitable in vitro substrate for $\mathrm{p} 38$ isoforms p38 and p38 $\gamma$, and its phosphorylation by these two enzymes reduces its ability to promote microtubule assembly [18,225-228]. Moreover, $\mathrm{p} 38 \gamma$ overexpression in neuroblastoma induces Tau phosphorylation, which is associated with a reduction in Tau that is associated with the cytoskeleton and an increase in soluble Tau. Furthermore, p38 is the major Tau kinase in neuroblastoma in response to osmotic shock [227]. This evidence indicates that p38 MAPKs potentially regulate Tau hyperphosphorylation in neurodegenerative diseases and are potentially suitable therapeutic targets for those diseases.

Other studies have focused on the receptor for advanced glycation end products (RAGE), a multiligand member of the immunoglobulin superfamily of cell surface molecules, which serves as a receptor for $A \beta$ on neurons, microglia, astrocytes, and endothelial cells of blood vessels. RAGE is upregulated in brain regions affected by AD. A murine transgenic model revealed that RAGE is a potential therapeutic target for $\mathrm{AD}$ [229].

Several studies have reported that EA and manual acupuncture have a therapeutic effect on AD. For example, EA at acupoint GV20 suppresses A $\beta$ generation [228]. Stimulation at acupoints GV14 and BL23 downregulates beta-secretase 1, which is an enzyme that is responsible for $A \beta$ generation in $\mathrm{AD}$ and increases hippocampal ATP levels in AD mice [230]. Low-frequency (2-Hz) EA at acupoint GV20 and bilateral acupoints KI3 and ST36 for 15 min once daily for 12 sessions was reported to significantly downregulate p-p38 MAPK and IL-1 $\beta$ mRNA expression in the hippocampus and the frontal lobe [65]. Other studies have reported that EA at GV20 reversed behavioral deficit and LTP impairment, possibly through the N-methyl-D-aspartate receptor 1 (NMDA-R1) and TRPV1 pathway, thus reversing NR1- (one of the NMDA receptor subunits) and TRPV1-mediated neurotoxicity in vascular dementia $[208,209]$. This implies that $2-\mathrm{Hz}$ EA can rescue 338 MAPK signal transduction, resulting in anti-apoptotic and anti-inflammatory effects that reduce $A \beta$ deposits in the brain and improve learning and memory in AD patients [20].

\subsection{Parkinson's Disease}

Parkinson's disease is a neurodegenerative disorder that causes severe motor impairment owing to loss of dopaminergic neurons in the substantia nigra pars compacta (SNpc). Several studies have focused on PD pathophysiology and reported potential therapeutic targets for PD.

One of the direct neuroprotective effects is exerted by the protein deglycase DJ-1, which inhibits ASK1 through the nuclear sequestration of death domain-associated protein (Daxx) [230-232]. DJ-1 is speculated to scavenge reactive oxidative species (ROS) and subsequently attenuate 
oxidative stress, thereby reducing cellular ROS burden $[233,234]$. Furthermore, DJ-1 interacts with p38-regulated/activated kinase (PRAK/MK5) under cellular oxidative stress to facilitate nuclear localization of DJ-1 [235]. Thus, DJ-1 co-localizes with PRAK in the nuclei of NIH3T3 cells. Since DJ-1 lacks both nuclear localization and nuclear export signals, PRAK may be a crucial factor assisting DJ-1 in regulating the cellular localization of Daxx and in ASK1 signaling and concomitant cell death [236].

A recent study reported that EA at acupoint KI3 reduced the excitotoxicity of dopaminergic neurons by regulating the NMDA receptor function and thus may potentially serve as a novel therapeutic approach for PD [237]. The levels of pNR1 and pNR2B, phosphorylated PKA, PKC, $\alpha-\mathrm{Ca} 2+/ \mathrm{CaMKII}, \mathrm{pERK}$, and CREB were also reduced following EA [237].

\section{Fibromyalgia}

Fibromyalgia is a common chronic pain syndrome characterized by chronic widespread mechanical pain. TRPV1 and TRPV4 are believed to play a crucial role in the pathophysiology of fibromyalgia. EA at $2 \mathrm{~Hz}$ at bilateral ST36 acupoints was reported to reduce long-lasting mechanical hyperalgesia by downregulating TRPV4, p-p38, p-JNK, and pCREB in the peripheral nervous system and CNS [238,239].

Taken together, acupuncture exerts anti-inflammation, anti-apoptosis, and neuroprotection effects via modulating proinflammatory cytokines, increasing the levels of neurotrophic factors and modulating signaling pathways, such as p38 MAPKs, Raf/MAPK/ERK1/2, TLR4/ERK, PI3K/AKT, AC/cAMP/PKA, ASK1-JNK/p38, and downstream CREB, JNK, m-TOR, NF- $\mathrm{kB}$, and Bcl-2/Bax balance. EA relieves acute pain through inhibiting the TRPV1 signaling and PI3K/PKC/CaMKII pathway. EA also promote the release of opiates to activate $\mu-, \delta-$, and $\kappa$-opioid receptors, therefore producing immediate and persistent analgesic effects. Furthermore, EA can downregulate TRPV1-mediated inflammation and the release of proinflammatory cytokines, GFAP, Iba-1, and S100B by inhibiting the phosphorylation of p38 MAPK, therefore inhibiting microglial activation that triggers nerve damage and pain. Combining acupuncture to the treatment of a cerebral ischemic/hemorrhagic event can have a positive effect; an upregulation of BDNF synthesis, downregulation of P2X4Rs, and inhibition of p38 phosphorylation leads to the activation of the Raf-1/MEK1/2/ERK1/2/p90RSK/Bad signaling pathway, which contributes to the downregulation of caspase-3-dependent neuronal apoptosis. Acupuncture also inhibits the TNF- $\alpha$ /TRADD/FADD/cleaved caspase-8/cleaved caspase- 3 apoptotic pathway in the ischemic cortical penumbra after reperfusion. In the case of treating epilepsy and seizure, several antiepileptic mechanisms have been proposed, including the downregulation of JNK or ERK1/2 and proinflammatory factors (IL- $1 \beta$, IL-6, TNF- $\alpha$ ) in the cerebral cortex and hippocampus. Auricular EA can reduce hippocampal hyperactivity through TRPA1 and PKC $\varepsilon / \mathrm{PKC} \alpha / \mathrm{pERK} 1 / 2$ signaling pathways. Furthermore, acupuncture can regulate $\mathrm{p} 38 \gamma$ and $\mathrm{p} 38 \delta$ and reduce Tau hyperphosphorylation in neurodegenerative diseases. Acupuncture also exhibits a therapeutic effect that was reported to involve the regulation of DJ-1, ASK1, Daxx, phosphorylated PKA, PKC, $\alpha$-Ca2+/CaMKII, pERK, and CREB. Acupuncture exerts curative effects in migraine through local analgesia, anti-inflammation, neuropeptide regulation, cytoskeleton remodeling, cell repair, and improvement in overall homeostasis. Furthermore, the downregulation of TRPV4, p-p38, p-JNK, and pCREB in the peripheral nervous system and CNS may account for the therapeutic effect of acupuncture in fibromyalgia.

This literature review based on the results of previous studies where we electronically searched databases including PubMed, Embase, and the Cochrane Library from their inception to April 2020, using the following keywords alone or in various combinations: "acupuncture", "p38 MAPK pathway", "signaling", "stress response", "inflammation", "immune", "pain", "analgesic", "cerebral ischemic injury", "epilepsy", "Alzheimer's disease", "Parkinson's disease", "dementia", "degenerative", and "homeostasis". The schematic explanation of the searching process is presented as Appendix A.

\section{Conclusions}

Among the aforementioned cell pathways, the p38 MAPK signaling pathway plays a role in the therapeutic effect of acupuncture in several nervous system diseases. EA inhibits the ascending pain 
pathway and intracellular p38-mediated inflammatory pathway by stimulating peripheral opioid receptors. Furthermore, EA promotes endogenic analgesic mechanisms, thus exerting immediate local analgesic effects and rescuing CNS-induced chronic pain. Acupuncture also counteracts p38 MAPK signal transduction, reduces $A \beta$ deposits in the brain, and improves learning and memory in AD patients.

Acupuncture exhibits a dual regulatory function through the activation or inhibition of different p38 MAPK pathways and contributes to an overall improvement of clinical symptoms and physiological functions in several nervous system diseases. The p38 MAPK pathway potentially induces both protective and inhibitory effects in highly similar systems. Further studies are required to identify and characterize the various substrates of these kinases involved in cell differentiation/cell repair, neurotoxicity, and neurodegeneration, thus potentially furthering the current understanding of the mechanism underlying acupuncture in treating these diseases.

Author Contributions: Data curation, T.-H.W.; writing-original draft preparation, T.-H.W.; review and editing, C.-L.H. All authors have read and agreed to the published version of the manuscript.

Funding: This study was financially supported by the Chinese Medicine Research Center, China Medical University from the Featured Areas Research Center Program within the framework of the Higher Education Sprout Project by the Ministry of Education in Taiwan (CMRC-CENTER-0).

Conflicts of Interest: The authors declare no conflicts of interest.

\section{Abbreviations}

A1R
$\alpha 7$ nAChR
AC
ACC1
AD
Akt (PKB)
Alk5
AMP
AMPK
AP-1
ARE
ASIC3
ASK-1
ATF
ATP
BACE1
Bad
Bax
Bac-2
BDNF
CaMKII
CCI
Cd242
CFA-treated
c-Fos
CHOP
c-Jun

adenosine A1 receptor

$\alpha 7$ nicotinic acetylcholine receptor

adenyl cyclase

acetyl-CoA carboxylase (ACC) 1 is a biotin-dependent enzyme that catalyzes the

irreversible carboxylation of acetyl-CoA to produce malonyl-CoA

Alzheimer's disease

protein kinase $\mathrm{B}(\mathrm{PKB})$ is also known as Akt

TGF $\beta$ type I receptor kinase

adenosine mono-phosphate

5' AMP-activated protein kinase

activator protein 1

AU-rich elements

acid-sensing ion channel 3

apoptosis signal-regulating kinase 1

activating transcription factor

adenosine tri-phosphate

beta-secretase 1 , an enzyme responsible for $\mathrm{A} \beta$ generation in Alzheimer's disease

BCL2 associated agonist of cell death; a protein involved in initiating apoptosis.

Bcl-2 associated X

B-cell lymphoma 2

brain-derived neurotrophic factor

calmodulin-dependent protein kinase II

chronic constriction injury

The 40- to 42-kiloDalton red cell membrane glycoprotein bearing the ICAM-4 antigen named by the LW blood system.

Complete Freund's adjuvant injections produced significant mechanical and thermal hyperalgesia in mice.

A proto-oncogene that is expressed within some neurons following depolarization. C/EBP homologous protein; belongs to the family of CCAAT/enhancer-binding proteins (C/EBPs) and is involved in the regulation of genes that encode proteins involved in proliferation

A proto-oncogene that with c-Fos forms the AP-1 early response transcription factor that regulates gene expression in response to extracellular stimuli. 
CL100

CLCA3A2
CLIC3
Cot (Tp2)
COX-2
cPLA2
CREB
CRF
CWP
DLK (MAP3K12)
DJ-1
DLG1 (SAP97)
Daxx
DHT
DRG
EA
elF2a
eEF2
eEF2K
elF2 $\alpha$
Elk-1
ERK
ETS

FADD

Fas pathway

GABA

GFAP

GPCRs

HMG-CoA Reductase
Hsc70

Hsp

5-HT

Iba-1

I $\mathrm{B}$

$\mathrm{I} \kappa \mathrm{B}$

IKKs

IL-1 $\beta$

IRF

JNK

LTD

LTP

MA

MAPK

MAPKK (MAP2K, MKK)

MAPKKK (MAP3K)

Max
The human CL100 gene is induced in skin fibroblasts in response to oxidative/heat stress and growth factors. The CL100 gene encodes a dual specificity (Tyr/Thr) protein phosphatase that specifically inactivates MAPKs.

chloride channel accessory 3A2

chloride intracellular channel 3

cancer Osaka thyroid oncogene (=Tpl-2)

cyclooxygenase-2

cytosolic phospholipase A2

cAMP response element-binding protein

corticotropin-releasing factor

components of calcium wave propagation

dual leucine zipper kinase, also known as MAP3K12

a protein deglycase

discs large homolog 1 scaffold protein

the death-associated protein

dihydrotestosterone

dorsal root ganglion

electroacupuncture

eukaryotic translation initiation factor $2 \mathrm{~A}$; functions by a separate mechanism in eukaryotic translation

eukaryotic elongation factor 2

eukaryotic elongation factor 2 kinase

a subunit of the heterotrimeric eIF2 complex

erythroblast transformation specific (ETS) like-1 protein

extracellular signal-regulated kinases

erythroblast transformation specific protein, or E26 transformation-specific, or E-twenty-six transcription factors family

Fas-associated protein with death domain; also called MORT1

Fas and Fas Ligand (FasL) are involved in the regulation of cell death.

gamma-aminobutyric acid

glial fibrillary acidic protein; a marker of astrocytes

G-protein-coupled receptors

3-hydroxy-3-methyl-glutaryl-CoA reductase or HMGR is the rate-controlling enzyme of the mevalonate pathway, responsible for cholesterol and other isoprenoid

biosynthesis.

heat shock cognate 70

heat shock proteins

5-hydroxytryptamine

ionized calcium-binding adapter molecule 1

inhibitor of nuclear factor kappa-B

inhibitor of nuclear factor kappa-B kinase

I-kappa-B kinases

Interleukin 1 beta is a member of the interleukin 1 family of cytokines produced by activated macrophages.

interferon regulatory factor

c-Jun amino-terminal kinases

long-term depression; a term in neurophysiology describing an activity-dependent reduction in the efficacy of neuronal synapses lasting hours or longer following a long patterned stimulus.

long-term potentiation; a persistent strengthening of synapses based on recent patterns of activity. These are patterns of synaptic activity that produce a long-lasting increase in signal transmission between two neurons.

manual acupuncture

mitogen-activated protein kinase

MAPK kinase

MAPKK kinase

a transcription factor coded by the myc-associated factor $X$ 


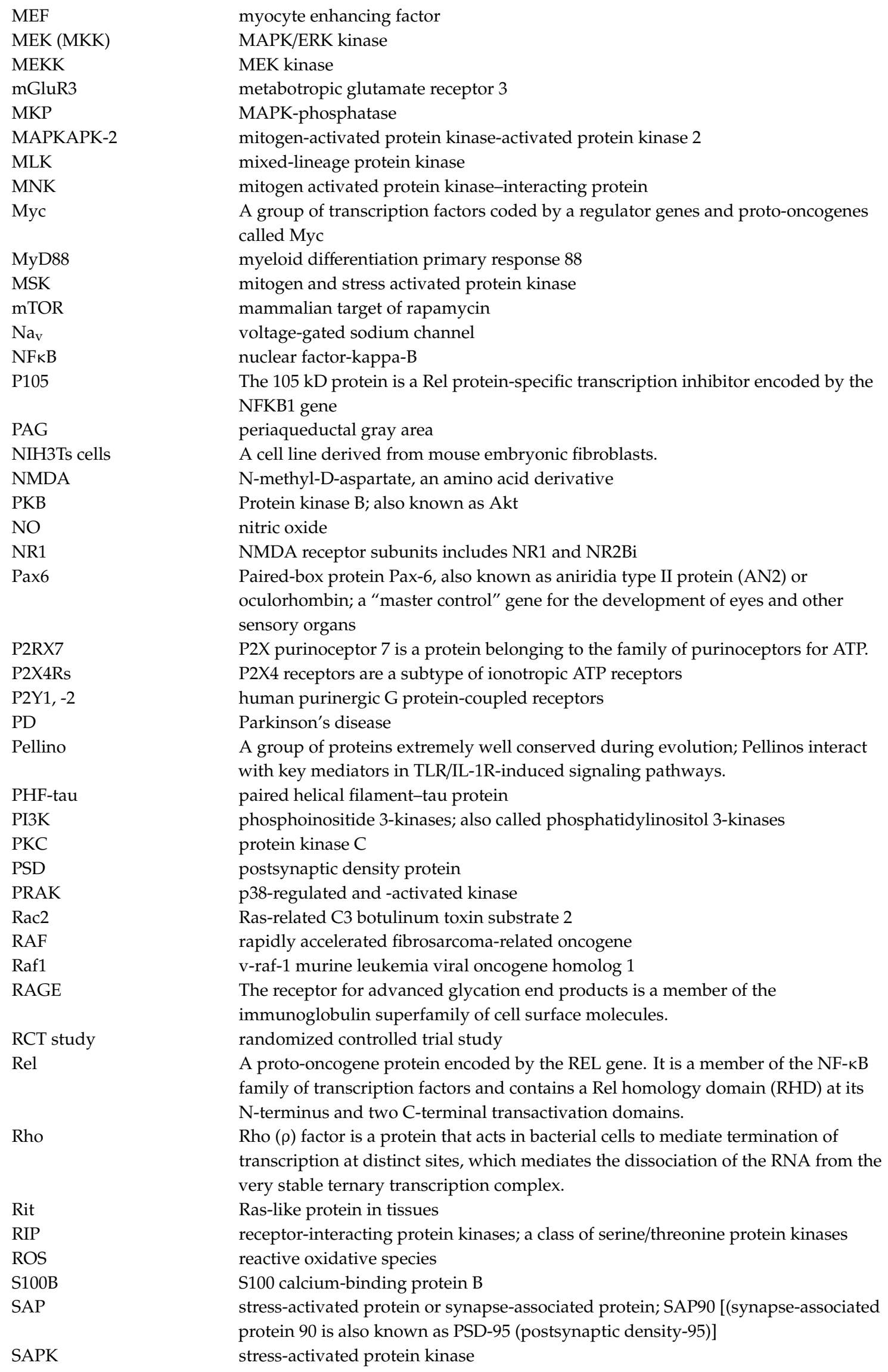


Smac/DIABLO

$\mathrm{SNpc}$

Stat1

STK

TAES

TAK-1

TAO

TAB1

TGF $\beta$

TLR4

TNF

Tpl2

TRADD

TRAF6

TrkB

TRPA1

TRPV

3'UTR second mitochondrial-derived activator of caspase/direct inhibitor of apoptosis protein-binding protein with low isoelectric point

substantia nigra pars compacta

signal transducer and activator of transcription 1

serine-threonine/tyrosine kinases

transcutaneous acupoint electrical stimulation

transforming growth factor- $\beta$-activated kinase 1

thousand and one amino acids

TGF-beta-activated kinase

transforming growth factor- $\beta$

toll-like receptor 4

tumor necrosis factor

tumor progression locus 2, also known as COT or MAP3K8

tumor necrosis factor receptor type 1-associated DEATH domain protein

tumor necrosis factor receptor (TNFR)-associated factor 6

tyrosine kinase receptor $\mathrm{B}$

transient receptor potential cation channel subfamily A member 1

transient receptor potential vanilloid receptors

3'untranslated region

\section{Appendix A}

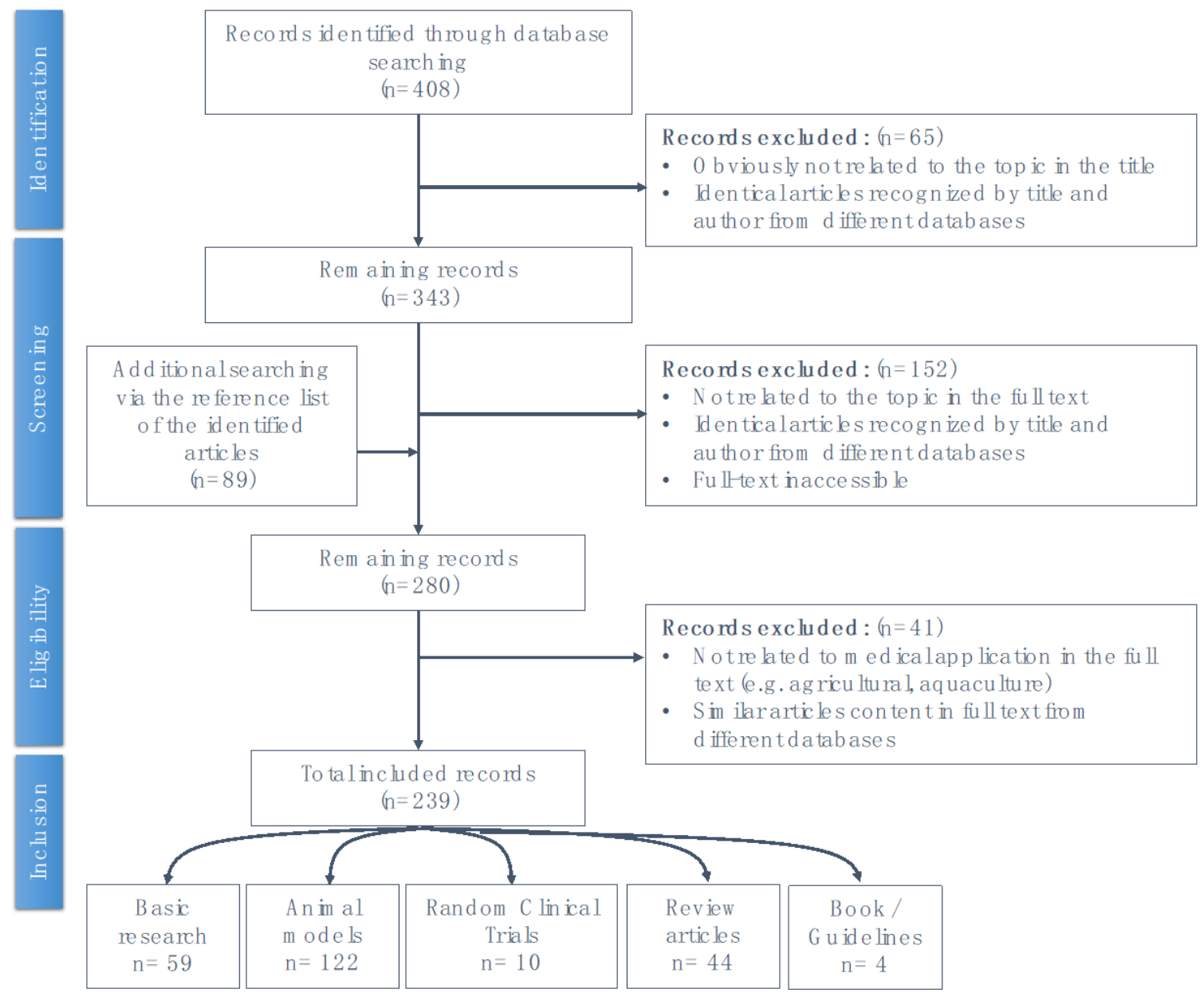

Figure A1. Schematic of the literature review search process. 


\section{References}

1. Zhou, W.; Benharash, P. Effects and mechanisms of acupuncture based on the principle of meridians. J. Acupunct. Meridian Stud. 2014, 7, 190-193. [CrossRef] [PubMed]

2. Wang, B.; Wu, N.L.; Wu, A.Q. The Yellow Emperor's Canon of Internal Medicine, 1st ed.; China Science \& Technology. Press: Beijing, China, 1997; 1999, 2nd edition.

3. Bannerman, R.H. Acupuncture: The WHO View; World Health Organization: Geneva, Switzerland, 1979; Volume 12, p. 27e8.

4. Park, J.; Sohn, Y.; White, A.R.; Lee, H. The safety of acupuncture during pregnancy: A systematic review. Acupunct. Med. 2014, 32, 257-266. [CrossRef] [PubMed]

5. Yang, C.; Hao, Z.; Zhang, L.L.; Guo, Q. Efficacy and safety of acupuncture in children: An overview of systematic reviews. Pediatr. Res. 2015, 78, 112-119. [CrossRef] [PubMed]

6. Fan, A.Y.; Miller, D.W.; Bolash, B.; Bauer, M.; McDonal, J.; Faggert, S.; He, H.; Li, Y.M.; Matecki, A.; Camardella, L.; et al. Acupuncture's role in solving the opioid epidemic: Evidence, cost-effectiveness, and care availability for acupuncture as a primary, nonpharmacologic method for pain relief and management-white paper. J. Integr. Med. 2017, 15, 411-425. [CrossRef]

7. Acupuncture: In Depth. National Center for Complementary and Alternative Medicine. Available online: https://nccih.nih.gov/health/acupuncture/introduction (accessed on 25 January 2020).

8. Hsieh, C.L. Acupuncture as treatment for nervous system diseases. BioMed 2012, 2, 51-57. [CrossRef]

9. He, X.R.; Wang, Q.; Li, P.P. Acupuncture and moxibustion for cancer-related fatigue: A systematic review and meta-analysis. Asian Pac. J. Cancer Prev. 2013, 14, 3067-3074. [CrossRef]

10. Cox, J.; Varatharajan, S.; Côté, P.; Optima Collaboration. Effectiveness of acupuncture therapies to manage musculoskeletal disorders of the extremities: A systematic review. J. Orthop. Sports Phys. Ther. 2016, 46, 409-429. [CrossRef]

11. Forde, J.C.; Jaffe, E.; Stone, B.V.; Te, A.E.; Espinosa, G.; Chughtai, B. The role of acupuncture in managing overactive bladder: A review of the literature. Int. Urogynecol. J. 2016, 27, 1645-1651. [CrossRef]

12. Yao, Q.; Li, S.; Liu, X.; Qin, Z.; Liu, Z. The effectiveness and safety of acupuncture for patients with chronic urticaria: A systematic review. Biomed Res. Int. 2016, 2016, 5191729. [CrossRef]

13. Bäcker, M.; Hammes, M.G.; Valet, M.; Deppe, M.; Valet, M.; Conrad, B.; Tölle, T.R.; Doboset, G. Different modes of manual acupuncture stimulation differentially modulate cerebral blood flow velocity, arterial blood pressure and heart rate in human subjects. [published correction appears in Neurosci. Lett. 2003, 6, 337, 117]. Neurosci. Lett. 2002, 333, 203-206. [CrossRef]

14. Hsieh, C.L.; Chang, Q.Y.; Lin, I.H.; Lin, J.G.; Liu, C.H.; Tang, N.Y.; Lane, H.Y. The study of electroacupuncture on cerebral blood flow in rats with and without cerebral ischemia. Am. J. Chin. Med. 2006, 34, 351-361. [CrossRef] [PubMed]

15. Kuo, C.; Lin, Y.; Tang, N.; Cheng, C.Y.; Hsieh, C.L. Electric stimulation of the ears ameliorated learning and memory impairment in rats with cerebral ischemia-reperfusion injury. Sci. Rep. 2016, 6, 20381. [CrossRef] [PubMed]

16. Bachstetter, A.D.; Xing, B. Microglial p38alpha MAPK is a key regulator of proinflammatory cytokine up-regulation induced by toll-like receptor (TLR) ligands or beta-amyloid (Abeta). J. Neuroinflammation 2011, 8, 79. [CrossRef] [PubMed]

17. Jin, Y.; Fan, Y. Effects of sodium ferulate on amyloid-beta-induced MKK3/MKK6-p38 MAPK-Hsp27 signal pathway and apoptosis in rat hippocampus. Acta Pharm. Sin. 2006, 27, 1309-1316. [CrossRef]

18. Yang, L.; Zhou, R. Neuroprotection by dihydrotestosterone in LPS-induced neuroinflammation. Neurobiol. Dis. 2020, 104814. [CrossRef]

19. Yan, S.D.; Bierhaus, A. RAGE and Alzheimer's disease: A progression factor for amyloid-beta-induced cellular perturbation? J. Alzheimers Dis 2009, 16, 833-843. [CrossRef]

20. Tang, Y.; Xu, A.; Shao, S.; Zhou, Y.; Xiong, B.; Li, Z. Electroacupuncture ameliorates cognitive impairment by inhibiting the JNK signaling pathway in a mouse model of Alzheimer's disease. Front. Aging Neurosci. 2020, 12, 23. [CrossRef]

21. Wang, K.; Wu, H.; Wang, G.; Li, M.; Zhang, Z.; Gu, G. The effects of electroacupuncture on TH1/TH2 cytokine mRNA expression and mitogen-activated protein kinase signaling pathways in the splenic T cells of traumatized rats. Anesth Analg. 2009, 109, 1666-1673. [CrossRef] 
22. Cheng, K.J. Neurobiological mechanisms of acupuncture for some common illnesses: A clinician's perspective. J. Acupunct. Meridian Stud. 2014, 7, 105-114. [CrossRef]

23. Xue, X.; You, Y.; Tao, J.; Ye, X.; Huang, J.; Yang, S.; Lin, Z.; Hong, Z.; Peng, J.; Chen, L. Electro-acupuncture at points of Zusanli and Quchi exerts anti-apoptotic effect through the modulation of PI3K/Akt signaling pathway. Neurosci. Lett. 2014, 558, 14-19. [CrossRef]

24. Wang, H.; Wang, L.; Liang, F.; Liu, J.; Li, J.; Lu, J.; Fu, Y.; Chen, Q.; Has, Q.; Wu, S. Effects of electroacupuncture on electrocardiogram, myocardial pathological morphology and PI3K/Akt pathway in rats with chronic myocardial ischemia. Zhongguo Zhen Jiu 2016, 36, 389-395.

25. Hwang, I.K.; Chung, J.Y.; Yoo, D.Y.; Yi, S.S.; Youn, H.Y.; Seong, J.K.; Soon, Y.S. Effects of electroacupuncture at Zusanli and Baihui on brain-derived neurotrophic factor and cyclic AMP response element-binding protein in the hippocampal dentate gyrus. J. Vet. Med. Sci. 2010, 72, 1431-1436. [CrossRef] [PubMed]

26. Zhang, H.; Qin, F.; Liu, A.; Sun, Q.; Wang, Q.; Xie, S.; Lu, S.; Zhang, D.; Lu, Z. Electro-acupuncture attenuates the mice premature ovarian failure via mediating PI3K/AKT/mTOR pathway. Life Sci. 2019, 217, 169-175. [CrossRef] [PubMed]

27. Du, J.; Wang, Q.; Hu, B.; Peng, Z.; Zhao, Y.; Ma, L.; Xiong, L.; Lu, Y.; Zhu, X.; Chen, S. Involvement of ERK 1/2 activation in electroacupuncture pretreatment via cannabinoid CB1 receptor in rats. Brain Res. 2010, 1360, 1-7. [CrossRef]

28. Xie, G.; Yang, S.; Chen, A.; Lan, L.; Lin, Z.; Gao, Y.; Huang, J.; Lin, J.; Peng, J.; Tao, J.; et al. Electroacupuncture at Quchi and Zusanli treats cerebral ischemia-reperfusion injury through activation of ERK signaling. Exp. Ther. Med. 2013, 5, 1593-1597. [CrossRef] [PubMed]

29. Wu, C.; Wang, J.; Chun, L.; Zhou, G.; Xu, X.; Zhang, X.; Lan, X. Effect of electroacupuncture on cell apoptosis and erk signal pathway in the hippocampus of adult rats with cerebral ischemia-reperfusion. Evid. Based Complementary Altern. Med. 2015, 414965. [CrossRef] [PubMed]

30. Wu, C.; Li, C.; Zhou, G.; Yang, L.; Jiang, G.; Chen, J.; Li, Q.; Zhan, Z.; Xu, X.; Zhang, X. Effects of electroacupuncture on the cortical extracellular signal regulated kinase pathway in rats with cerebral ischaemia/reperfusion. Acupunct. Med. 2017, 35, 430-436. [CrossRef] [PubMed]

31. Lin, D.; Wu, Q.; Lin, X.; Boriongan, C.; He, Z.; Tan, J.; Cao, C.; Zhou, S. Brain-derived neurotrophic factor signaling pathway: Modulation by acupuncture in telomerase knockout mice. Altern. Health Med. 2015, 21, $36-46$.

32. Wang, S.J.; Ma, J.; Gong, Y.X.; Wang, Y.C.; Zeng, X.L.; Liang, Y.; Sun, G.J. Effect of electroacupuncture intervention on ERK 1/2 signaling and TNF-alpha and IL-1beta protein levels in the substantia nigra in rats with Parkinson's disease. Zhen Ci Yan Jiu 2014, 39, 456-460.

33. Lan, X.; Zhang, X.; Zhou, G.P.; Wu, C.X.; Li, C.; Xu, X.H. Electroacupuncture reduces apoptotic index and inhibits $\mathrm{p} 38$ mitogen-activated protein kinase signaling pathway in the hippocampus of rats with cerebral ischemia/reperfusion injury. Neural Regen. Res. 2017, 12, 409-416. [CrossRef]

34. Xing, Y.; Yang, S.D.; Wang, M.M.; Dong, F.; Feng, Y.S.; Zhang, F. Electroacupuncture alleviated neuronal apoptosis following ischemic stroke in rats via midkine and ERK/JNK/p38 signaling pathway. J. Mol. Neurosci. 2018, 66, 26-36. [CrossRef]

35. Liu, W.; Wang, X.; Yang, S.; Huang, J.; Xue, X.; Zheng, Y.; Shang, G.; Tao, J.; Chen, L. Electroacupunctre improves motor impairment via inhibition of microglia-mediated neuroinflammation in the sensorimotor cortex after ischemic stroke. Life Sci. 2016, 151, 313-322. [CrossRef]

36. Xu, J.; She, Y.; Su, N.; Zhang, R.; Lao, L.; Xu, S. Effects of electroacupuncture on chronic unpredictable mild stress rats depression-like behavior and expression of p-ERK/ERK and p-P38/P38. Evid. Based Complement Altern. Med. 2015, 2015, 650729. [CrossRef] [PubMed]

37. Yang, X.; Guo, Z.; Lu, J.; Zhao, B.; Fei, Y.; Li, J.; Jiang, H.; Sun, L.; Wang, Y.; Sun, Y.; et al. The Role of MAPK and dopaminergic synapse signaling pathways in antidepressant effect of electroacupuncture pretreatment in chronic restraint stress rats. Evid. Based Complementary Altern. Med. 2017, 2017, 2357653. [CrossRef] [PubMed]

38. Duan, D.M.; Dong, X.; Tu, Y.; Liu, P. A microarray study of chronic unpredictable mild stress rat blood serum with electro-acupuncture intervention. Neurosci. Lett. 2016, 627, 160-167. [CrossRef]

39. Zhao, G.; Li, D.; Ding, X.; Li, L. Nerve growth factor pretreatment inhibits lidocaine-induced myelin damage via increasing BDNF expression and inhibiting p38 mitogen activation in the rat spinal cord. Mol. Med. Rep. 2017, 16, 4678-4684. [CrossRef] [PubMed] 
40. Liao, E.T.; Lin, Y.W.; Huang, C.P.; Tang, N.Y.; Hsieh, C.L. Electric stimulation of ear reduces the effect of Toll-like receptor 4 signaling pathway on kainic acid-induced epileptic seizures in rats. Biomed. Res. Int. 2018, 2018, 5407256. [CrossRef] [PubMed]

41. Feng, X.; Yang, S.; Liu, J.; Huang, J.; Peng, J.; Lin, J.; Tao, J.; Chen, L. Electroacupuncture ameliorates cognitive impairment through inhibition of NF-kB-mediated neuronal cell apoptosis in cerebral ischemia-reperfusion injured rats. Mol. Med. Rep. 2013, 7, 1516-1522. [CrossRef]

42. Lan, L.; Tao, J.; Chen, A.; Xie, G.; Huang, J.; Lin, J.; Peng, J.; Chen, L. Electroacupuncture exerts anti-inflammatory effects in cerebral ischemia-reperfusion injured rats via suppression of the TLR4/NF- $\mathrm{B}$ pathway. Int. J. Mol. Med. 2013, 31, 75-80. [CrossRef]

43. Zhu, Y.; Zeng, Y.; Wang, X.; Ye, X. Effect of electroacupuncture on the expression of mTOR and eIF4E in hippocampus of rats with vascular dementia. Neurol. Sci. 2013, 34, 1093-1097. [CrossRef]

44. Xu, T.; Li, W.; Liang, Y.; Yang, Z.; Liu, J.; Wang, Y.; Su, N. Neuroprotective effects of electro acupuncture on hypoxic-ischemic encephalopathy in newborn rats Ass. Pak. J. Pharm. Sci. 2014, 27 (Suppl. 6), 1991-2000. [PubMed]

45. Oh, J.; Kim, Y.; Kim, S.; Lee, B.; Jang, J.; Kwon, S.; Park, H. Acupuncture modulates stress response by the mTOR signaling pathway in a rat post-traumatic stress disorder model. Sci. Rep. 2018, 8, 11864. [CrossRef] [PubMed]

46. Liu, W.; Zhuo, P.; Li, L.; Jin, H.; Lin, B.; Zhang, Y.; Liang, S.; Wu, J.; Huang, J.; Wang, Z.; et al. Activation of brain glucose metabolism ameliorating cognitive impairment in APP/PS1 transgenic mice by electroacupuncture. Free. Radic. Biol. Med. 2017, 112, 174-190. [CrossRef] [PubMed]

47. Kim, Y.R.; Kim, H.N.; Jang, J.Y.; Park, C.; Lee, J.H.; Shin, H.K.; Choi, Y.H.; Choi, B.T. Effects of electroacupuncture on apoptotic pathways in a rat model of focal cerebral ischemia. Int. J. Mol. Med. 2013, 32, 1303-1310. [CrossRef] [PubMed]

48. Lawan, A.; Bennett, A.M. Mitogen-activated protein kinase regulation in hepatic metabolism. Trends Endocrinol. Metab. 2017, 28, 868-878. [CrossRef] [PubMed]

49. Kim, S.N.; Kim, S.T.; Doo, A.R.; Park, J.Y.; Moon, W.; Chae, Y.; Yin, C.S.; Lee, H.; Park, H.J. Phosphatidylinositol 3-kinase/Akt signaling pathway mediates acupuncture-induced dopaminergic neuron protection and motor function improvement in a mouse model of Parkinson's disease. Int. J. Neurosci. 2011, 121, 562-569. [CrossRef]

50. Kim, S.N.; Doo, A.R.; Park, J.Y.; Bae, H.; Chae, Y.; Shim, I.; Lee, H.; Moon, W.; Lee, H.; Park, H.J. Acupuncture enhances the synaptic dopamine availability to improve motor function in a mouse model of Parkinson's disease. PLoS ONE 2011, 6, e27566. [CrossRef]

51. Li, Q.Q.; Shi, G.X.; Yang, J.W.; Li, Z.H.; Zhang, Z.H.; He, T.; Wang, J.; Liu, L.Y.; Liu, C.Z. Hippocampal cAMP/PKA/CREB is required for neuroprotective effect of acupuncture. Physiol. Behav. 2015, 139, 482-490. [CrossRef]

52. Lu, F.; Zhu, H.M.; Xie, J.J.; Zhou, H.H.; Chen, Y.L.; Hu, J.Y. Effects of electroacupuncture on behavior, plasma COR and expressions of PKA and PKC in hippocampus of the depression model rat. Zhongguo Zhen Jiu 2008, $28,214-218$.

53. Liu, J.J.; Wu, Z.F.; Sun, J.; Jiang, L.; Jiang, S.; Fu, W.B. Role of AC-cAMP-PKA cascade in antidepressant action of electroacupuncture treatment in rats. Evid. Based Complementary Altern. Med. 2012, 2012, 932414. [CrossRef]

54. Lin, R.; Lin, Y.; Tao, J.; Chen, B.; You, K.; Chen, J.; Li, X.; Chen, L.D. Electroacupuncture ameliorates learning and memory in rats with cerebral ischemia-reperfusion injury by inhibiting oxidative stress and promoting p-CREB expression in the hippocampus. Mol. Med. Rep. 2015, 12, 6807-6814. [CrossRef]

55. Ahn, S.; Kim, Y.; Kim, H.; Shin, Y.I.; Shin, H.K.; Choi, B.T. Electroacupuncture ameliorates memory impairments by enhancing oligodendrocyte regeneration in a mouse model of prolonged cerebral hypoperfusion. Sci. Rep. 2016, 6, 28646. [CrossRef] [PubMed]

56. Zhang, Y.; Lin, R.; Tao, J.; Wu, Y.; Chen, B.; You, K.; Chen, J.; Li, X.; Chen, L.D. Electroacupuncture improves cognitive ability following cerebral ischemia reperfusion injury via CaM-CaMKIV-CREB signaling in the rat hippocampus. Exp. Ther. Med. 2016, 12,777-782. [CrossRef]

57. Yun, Y.C.; Jang, D.; Yoon, S.B.; Kim, D.; Choi, D.H.; Kwon, O.S.; Lee, Y.M.; Youn, D. Laser acupuncture exerts neuroprotective effects via regulation of $\mathrm{Creb}, \mathrm{Bdnf}, \mathrm{Bcl}-2$, and Bax gene expressions in the hippocampus. Evid. Based Complementary Altern. Med. 2017, 2017, 7181637. [CrossRef] 
58. Pak, M.E.; Jung, D.H.; Lee, H.J.; Shin, M.J.; Kim, S.Y.; Shin, Y.B.; Yun, Y.J.; Shin, H.K.; Choi, B.T. Combined therapy involving electroacupuncture and treadmill exercise attenuates demyelination in the corpus callosum by stimulating oligodendrogenesis in a rat model of neonatal hypoxia-ischemia. Exp. Neurol. 2018, 300, 222-231. [CrossRef] [PubMed]

59. Lu, J.; Liang, J.; Wang, J.R.; Hu, L.; Tu, Y.; Guo, J.Y. Acupuncture activates ERK-CREB pathway in rats exposed to chronic unpredictable mild stress. Evid. Based Complementary Altern. Med. 2013, 2013, 469765. [CrossRef]

60. Dimaras, H.; Gallie, B.L. Retinoblastoma Protein, Biological and Clinical Functions. In Encyclopedia of Cancer; Schwab, M., Ed.; Springer: Berlin/Heidelberg, Germany, 2011; pp. 4046-4050. [CrossRef]

61. Duval, D.; Trouillas, M.; Thibault, C.; Dembelé, D.; Diemunsch, F.; Reinhardt, B.; Mertz, A.L.; Dierich, A.; Boeuf, H. Apoptosis and differentiation commitment: Novel insights revealed by gene profiling studies in mouse embryonic stem cells. Cell Death Differ. 2005, 13, 564-575. [CrossRef]

62. Wang, Y.; Jiang, H.; Meng, H.; Li, J.; Yang, X.; Zhao, B.; Sun, Y.; Bro, T. Antidepressant mechanism research of acupuncture: Insights from a genome-wide transcriptome analysis of frontal cortex in rats with chronic restraint stress. Evid. Based Complementary Altern. Med. 2017, 2017, 1676808. [CrossRef]

63. Liu, J.; Wang, Q.; Yang, S.; Huang, J.; Feng, X.; Peng, J.; Lin, Z.; Liu, W.; Tao, W.; Chen, L. Electroacupuncture inhibits apoptosis of peri-ischemic regions via modulating p38, extracellular signal-regulated kinase (ERK1/2), and c-Jun $\mathrm{N}$ terminal kinases (JNK) in cerebral ischemia-reperfusion-injured rats. Med. Sci. Monit. 2018, 24, 4395-4404. [CrossRef]

64. Zhu, Y.; Deng, L.; Tang, H.; Gao, X.; Wang, Y.; Guo, K.; Kong, J.; Yang, C. Electroacupuncture improves neurobehavioral function and brain injury in rat model of intracerebral hemorrhage. Brain Res. Bull. 2017, 131, 123-132. [CrossRef]

65. Li, Z.; Zheng, X.; Li, P.; Itoua, E.S.; Moukassa, D.; Ndinga Andely, F. Effects of acupuncture on mRNA levels of apoptotic factors in perihematomal brain tissue during the acute phase of cerebral hemorrhage. Med. Sci. Monit. 2017, 23, 1522-1532. [CrossRef] [PubMed]

66. Li, X.Y.; Xu, L.; Liu, C.L.; Huang, L.S.; Zhu, X.Y. Electroacupuncture Intervention inhibits the decline of learning-memory ability and overexpression of cleaved Caspase-3 and Bax in hippocampus induced by isoflurane in APPswe/PS 1. Zhen Ci Yan Jiu 2016, 41, 24-30.

67. Wang, T.; Liu, C.Z.; Yu, J.C.; Jiang, W.; Han, J.X. Acupuncture protected cerebral multi-infarction rats from memory impairment by regulating the expression of apoptosis related genes Bcl-2 and Bax in hippocampus. Physiol. Behav. 2009, 96, 155-161. [CrossRef] [PubMed]

68. Tian, W.J.; Huang, L.N.; Wang, R.H.; An, J.M.; Zhang, M. Effects of scalp-acupuncture on astrocyte apoptosis in hippocampal CA 1 region in rats with vascular dementia. Zhen Ci Yan Jiu 2015, 40, 6-12. [PubMed]

69. Lai, H.C.; Chang, Q.Y.; Hsieh, C.L. Signal transduction pathways of acupuncture for treating some nervous system diseases. Evid. Based Complement. Altern. Med. 2019, 2019, 2909632. [CrossRef] [PubMed]

70. Fang, J.Q.; Zhu, S.X.; Zhang, Y.; Wang, F.; Zhu, Q.Y. Effects of transcutaneous electrostimulation of auricular points on behavior and hippocampal IL-1 $\beta$ and TNF- $\alpha$ expression in temporal lobe epilepsy rats. Acupunct. Res. 2016, 41, 283-290.

71. Ding, X.; Yu, J.; Yu, T.; Fu, Y.; Han, J. Acupuncture regulates the aging-related changes in gene profile expression of the hippocampus in senescence-accelerated mouse (SAMP10). Neurosci. Lett. 2006, 399, 11-16. [CrossRef]

72. Zhang, M.; Xv, G.; Wang, W.; Meng, D.; Ji, Y. Electroacupuncture improves cognitive deficits and activates PPAR- $\gamma$ in a rat model of Alzheimer's disease. Acupunct. Med. 2017, 35, 44-51. [CrossRef]

73. Jia, Y.; Zhang, X.; Yu, J.; Han, J.; Yu, T.; Shi, J.; Zhao, L.; Nie, K. Acupuncture for patients with mild to moderate Alzheimer's disease: A randomized controlled trial. BMC Complement Altern. Med. 2017, 17, 556. [CrossRef]

74. Zhou, S.; Dong, L.; He, Y.; Xiao, H. Acupuncture plus herbal medicine for Alzheimer's disease: A systematic review and meta-analysis. Am. J. Chin. Med. 2017, 45, 1327-1344. [CrossRef]

75. Zhu, W.; Wang, X.; Du, S.; Yan, C.; Yang, N.; Lin, L.; Shi, G.; Liu, C. Anti-oxidative and anti-apoptotic effects of acupuncture: Role of thioredoxin-1 in the hippocampus of vascular dementia rats. Neuroscience 2018, 379, 281-291. [CrossRef]

76. Wang, S.; Fang, J.; Ma, J.; Wang, Y.; Zeng, X.; Zhou, D.; Sun, G. Influence of electroacupuncture on p38-mitogen activated protein kinase in substantia nigra cells of rats with Parkinson disease model. Zhongguo Zhen Jiu 2013, 33, 329-333. [PubMed] 
77. Krens, S.F.; Spaink, H.P.; Snaar-Jagalska, B. Functions of the MAPK family in vertebrate-development. FEBS Lett. 2006, 580, 4984-4990. [CrossRef] [PubMed]

78. Roux, P.P.; Blenis, J. ERK and p38 MAPK-activated protein kinases: A family of protein kinases with diverse biological functions. Microbiol. Mol. Biol. Rev. 2004, 68, 320-344. [CrossRef]

79. Ajibade, A.A.; Wang, Q. TAK1 negatively regulates NF-kappaB and p38 MAP kinase activation in Gr-1+CD11b+ neutrophils. Immunity 2012, 36, 43-54. [CrossRef] [PubMed]

80. Brand, S. Crohn's disease: Th1, Th17 or both? The change of a paradigm: New immunological and genetic insights implicate Th17 cells in the pathogenesis of Crohn's disease. Gut 2009, 58, 1152-1167. [CrossRef]

81. Hannigan, M.; Zhan, L. The role of p38 MAP kinase in TGF-beta1-induced signal transduction in human neutrophils. Biochem. Biophys. Res. Commun. 1998, 346, 55-58. [CrossRef]

82. Heineke, J.; Molkentin, J.D. Regulation of cardiac hypertrophy by intracellular signalling pathways. Nat. Rev. Mol. Cell Biol. 2006, 77, 589-600. [CrossRef]

83. Shiojima, I.; Walsh, K. Regulation of cardiac growth and coronary angiogenesis by the Akt/PKB signaling pathway. Genes Dev. 2006, 20, 3347-3365. [CrossRef]

84. Shioi, T.; Kang, P.M. The conserved phosphoinositide 3-kinase pathway determines heart size in mice. EMBO J. 2000, 19, 2537-2548. [CrossRef]

85. Tanike, M.; Yamaguchi, O. Apoptosis signal-regulating kinase 1/p38 signaling pathway negatively regulates physiological hypertrophy. Circulation 2008, 117, 545-552. [CrossRef] [PubMed]

86. Solinas, G.; Becattini, B. JNK at the crossroad of obesity, insulin resistance, and cell stress response. Mol. Metab. 2017, 6, 174-184. [CrossRef] [PubMed]

87. Hotamisligil, G.S.; Davis, R.J. Cell Signaling and Stress Responses. Cold Spring Harb. Perspect. Biol. 2016, 8. [CrossRef]

88. Ning, C.; Wang, X. Chicory inulin ameliorates type 2 diabetes mellitus and suppresses JNK and MAPK pathways in vivo and in vitro. Mol. Nutr. Food Res. 2017, 61. [CrossRef]

89. Koh, A.; Molinaro, A. Microbially produced imidazole propionate impairs insulin signaling through mTORC1. Cell 2018, 175, 947-961.e17. [CrossRef] [PubMed]

90. Eagleton, M.J. Inflammation in abdominal aortic aneurysms: Cellular infiltrate and cytokine profiles. Vascular 2012, 20, 278-283. [CrossRef] [PubMed]

91. Abdul-Hussien, H.; Soekhoe, R.G. Collagen degradation in the abdominal aneurysm: A conspiracy of matrixmetalloproteinase and cysteine collagenases. Am. J. Pathol. 2007, 170, 809-817. [CrossRef]

92. Saratzis, A.; Abbas, A.A. Abdominal aortic aneurysm: A review of the genetic basis. Angiology 2011, 62, 18-32. [CrossRef]

93. Saratzis, A.; Kitas, G.D. Can statins suppress the development of abdominal aortic aneurysms? A review of the current evidence. Angiology 2010, 61, 137-144. [CrossRef]

94. Papalambros, E.; Sigala, F. Immunohistochemical expression of metalloproteinases MMP-2 and MMP-9 in abdominal aortic aneurysms: Correlation with symptoms and aortic diameter. Int. J. Mol. Med. 2003, 12, 965-968. [CrossRef]

95. Petersen, E.; Gineitis, A. Activity of matrix metalloproteinase-2 and -9 in abdominal aortic aneurysms. Relation to size and rupture. Eur. J. Vasc. Endovasc. Surg. 2000, 20, 457-461. [CrossRef] [PubMed]

96. Yang, C.Q.; Li, W. MCP-1 Stimulates MMP-9 expression via ERK 1/2 and p38 MAPK signaling pathways in human aortic smooth muscle cells. Cell Physiol. Biochem. 2014, 34, 266-276. [CrossRef] [PubMed]

97. Sun, Y.; Ma, C. Metabolism: A Novel Shared Link between Diabetes Mellitus and Alzheimer's Disease. J. Diabetes Res. 2020, 2020, 4981814. [CrossRef]

98. Kyriskis, J.M.; Avruch, J. Mammalian mitogen-activated protein kinase signal transduction pathways activated by stress and inflammation. Am. J. Physiol. 2001, 81, 808-869. [CrossRef]

99. Lang, E.; Bissinger, R.; Qadri, S.M.; Lang, F. Suicidal death of erythrocytes in cancer and its chemotherapy: A potential target in the treatment of tumor-associated anemia. Int. J. Cancer 2017, 141, 1522-1528. [CrossRef]

100. Brancho, D.; Tanaka, N.; Jaeschke, A.; Ventura, J.-J.; Kelkar, N.; Tanaka, Y.; Kyuuma, M.; Takeshita, T.; Flavell, R.A.; Davis, R.J. Mechanism of p38 MAP kinase activation in vivo. Genes Dev. 2003, 17, 1969-1978. [CrossRef]

101. Krishna, M.; Narang, H. The complexity of mitogen-activated protein kinases (MAPKs) made simple. Cell Mol. Life Sci. 2008, 65, 3525-3544. [CrossRef] [PubMed]

102. Bardwell, L. Mechanisms of MAPK signalling specificity. Biochem. Soc. Trans. 2006, 34, 837-841. [CrossRef] 
103. Akella, R.; Moon, T.M.; Goldsmith, E.J. Unique MAP kinase binding sites. Biochim. Biophys. Acta 2008, 1784, 48-55. [CrossRef]

104. Cuadrado, A.; Nebreda, A.R. Mechanisms and functions of p38 MAPK signalling. Biochim. J. 2010, 429, 403-417. [CrossRef]

105. Bonney, E.A. Mapping out p38MAPK. Am. J. Reporod. Immunol. 2017, 77. [CrossRef]

106. Wang, S.; Ding, L.; Ji, H.; Xu, Z.; Liu, Q.; Zheng, Y. The role of p38 MAPK in the development of diabetic cardiomyopathy. Int. J. Mol. Sci. 2016, 17, 1037. [CrossRef] [PubMed]

107. Chang, C.I.; Xu, B.E.; Cobb, M.H.; Goldsmith, E.J. Crystal structures of MAP kinase p38 complexed to the docking sites on its nuclear substrate MEF2A and activator MKK3b. Mol. Cell 2002, 9, 1241-1249. [CrossRef]

108. O'Callaghan, C.; Fanning, L.J.; Barry, O.P. p388 MAPK: Emerging Roles of a Neglected Isoform. Int. J. Cell Biol. 2014, 2014, 272689. [CrossRef] [PubMed]

109. Sabio, G.; Arthur, J.S.C.; Kuma, Y.; Peggie, M.; Carr, J.; Murray-Tait, V.; Centeno, F.; Goedert, M.; Morrice, N.A.; Cuenda, A. p38 $\gamma$ regulates the localisation of SAP97 in the cytoskeleton by modulating its interaction with GKAP. EMBO J. 2005, 24, 1134-1145. [CrossRef]

110. Parker, C.G.; Hunt, J.; Diener, K.; McGinley, M.; Soriano, B.; Keesler, G.A.; Bray, J.; Yao, Z.; Wang, X.S.; Kohno, T.; et al. Identification of stathmin as a novel substrate for p38 Delta. Biochem. Biophys. Res. Commun. 1998, 249, 791-796. [CrossRef]

111. Rubin, C.I.; Atweh, G.F. The role of stathmin in the regulation of the cell cycle. J. Cell Biochem. 2004, 93, 242-250. [CrossRef]

112. Knebel, A.; Morrice, N.; Cohen, P. A novel method to identify protein kinase substrates: eEF2 kinase is phosphorylated and inhibited by SAPK4/p386. EMBO J. 2001, 20, 4360-4369. [CrossRef] [PubMed]

113. Goedert, M.; Hasegawa, M.; Jakes, R.; Lawler, S.; Cuenda, A.; Cohen, P. Phosphorylation of microtubuleassociated protein tau by stress-activated protein kinases. FEBS Lett. 1997, 409, 57-62. [CrossRef]

114. Masuda, K.; Shima, H.; Watanabe, M.; Kikuchi, K. MKP-7, a novel mitogen-activated protein kinase phosphatase, functions as a shuttle protein. J. Biol. Chem. 2001, 276, 39002-39011. [CrossRef]

115. Kumar, G.S.; Clarkson, M.W.; Kunze, M.B.A.; Granata, D.; Wand, A.J.; Lindorff-Larsen, K.; Page, R.; Peti, W. Dynamic activation and regulation of the mitogen-activated protein kinase p38. Proc. Natl. Acad. Sci. USA 2018, 115, 4655-4660. [CrossRef]

116. Cuenda, A.; Rousseau, S. p38 MAP-Kinases pathway regulation, function and role in human disease. Biochim. Biophys. Acta 2007, 1773, 1358-1375. [CrossRef] [PubMed]

117. Wang, X.; McGowan, C.H.; He, L.; Downey, J.S.; Fearns, C.; Wang, Y.; Huang, S.; Han, J. Involvement of the MKK6-p38gamma cascade in gamma-radiation-induced cell cycle arrest. Mol. Cell Biol. 2000, 20, 4543-4552. [CrossRef]

118. Zhu, K.Q.; Zhang, S.J. Involvement of ATM/ATR-p38 MAPK cascade in MNNG induced G1-S arrest. World J. Gastroenterol. 2003, 9, 2073-2077. [CrossRef]

119. Tang, J.; Qi, X.; Mercola, D.; Han, J.; Chen, G. Essential role of p38gamma in K-Ras transformation independent of phosphorylation. J. Biol. Chem. 2005, 280, 23910-23917. [CrossRef] [PubMed]

120. Puri, P.L.; Wu, Z.; Zhang, P.; Wood, L.D.; Bhakta, K.S.; Han, J.; Feramisco, J.R.; Karin, M.; Wang, J.Y. Induction of terminal differentiation by constitutive activation of p38 MAP kinase in human rhabdomyosarcoma cells. Genes Dev. 2000, 14, 574-584. [PubMed]

121. Campbell, R.M.; Anderson, B.D.; Brooks, N.A.; Brooks, H.B.; Chan, E.M.; De Dios, A.; Gilmour, R.; Graff, J.R.; Jambrina, E.; Mader, M.; et al. Characterization of LY2228820 dimesylate, a potent and selective inhibitor of p38 MAPK with antitumor activity. Mol. Cancer 2014, 13, 364-374. [CrossRef]

122. Maimon, A.; Mogilevsky, M.; Shilo, A.; Golan-Gerstl, R.; Obiedat, A.; Ben-Hur, V.; Lebenthal-Loinger, I.; Stein, I.; Reich, R.; Beenstock, J.; et al. Mnk2 alternative splicing modulates the p38-MAPK pathway and impacts Ras-induced transformation. Cell Rep. 2014, 7, 501-513. [CrossRef] [PubMed]

123. Azijli, K.; Yuvaraj, S.; van Roosmalen, I.; Flach, K.; Giovannetti, E.; Peters, G.J.; de Jong, S.; Kruyt, F.A. MAPK p38 and JNK have opposing activities on TRAIL-induced apoptosis activation in NSCLC H460 cells that involves RIP1 and caspase-8 and is mediated by Mcl-1. Apoptosis 2013, 18, 851-860. [CrossRef] [PubMed]

124. Yuan, J.; Rozengurt, E. PKD, PKD2, and p38 MAPK mediate Hsp27 Serine-82 phosphorylation induced by neurotensin in pancreatic cancer PANC-1 cells. J. Cell Biochem. 2008, 103, 648-662. [CrossRef] 
125. Cánovas, B.; Igea, A.; Sartori, A.A.; Gomis, R.R.; Paull, T.T.; Isoda, M.; Pérez-Montoyo, H.; Serra, V.; González-Suárez, E.; Stracker, T.H.; et al. Targeting p38alpha increases DNA damage, chromosome instability, and the anti-tumoral response to taxanes in breast cancer cells. Cancer Cell 2018, 33, 1094-1110.e8. [CrossRef] [PubMed]

126. Junttila, M.R.; Ala-aho, R.; Jokilehto, T.; Peltonen, J.; Kallajoki, M.; Grenman, R.; Jaakkola, P.; Westermarck, J.; Kähäri, V.-M. p38 $\alpha$ and p38 mitogen-activated protein kinase isoforms regulate invasion and growth of head and neck squamous carcinoma cells. Oncogene 2007, 26, 5267-5279. [CrossRef] [PubMed]

127. Ringshausen, I.; Dechow, T.; Schneller, F.; Weick, K.; Oelsner, M.; Peschel, C.; Decker, T. Constitutive activation of the MAPkinase p38 is critical for MMP-9 production and survival of B-CLL cells on bone marrow stromal cells. Leukemia 2004, 18, 1964-1970. [CrossRef] [PubMed]

128. Gao, N.; Jiang, B.H.; Leonard, S.S.; Corum, L.; Zhang, Z.; Roberts, J.R.; Antonini, J.; Zheng, J.Z.; Flynn, D.C.; Castranova, V.; et al. p38 signaling-mediated hypoxia-inducible factor 1alpha and vascular endothelial growth factor induction by $\mathrm{Cr}(\mathrm{VI})$ in DU145 human prostate carcinoma cells. J. Biol. Chem. 2002, 277, 45041-45048. [CrossRef]

129. Kim, E.S.; Sohn, Y.W.; Moon, A. TGF-beta-induced transcriptional activation of MMP-2 is mediated by activating transcription factor (ATF)2 in human breast epithelial cells. Cancer Lett. 2007, 252, 147-156. [CrossRef]

130. Hong, I.K.; Kim, Y.M.; Jeoung, D.I.; Kim, K.C.; Lee, H. Tetraspanin CD9 induces MMP-2 expression by activating p38 MAPK, JNK and c-Jun pathways in human melanoma cells. Exp. Mol. Med. 2005, 37, $230-239$. [CrossRef] [PubMed]

131. Villa-Diaz, L.G.; Miyano, T. Activation of p38 MAPK during porcine oocyte maturation. Biol. Reprod. 2004, 71, 691-696. [CrossRef]

132. Lu, H.T.; Yang, D.D.; Wysk, M.; Gatti, E.; Mellman, I.; Davis, R.J.; Flavell, R.A. Defective IL-12 production in mitogen-activated protein (MAP) kinase kinase 3 (Mkk3)-deficient mice. EMBO J. 1999, 18, 1845-1857. [CrossRef]

133. Tanaka, N.; Kamanaka, M.; Enslen, H.; Dong, C.; Wysk, M.; Davis, R.J.; Flavelle, R.A. Differential involvement of p38 mitogen-activated protein kinase kinases MKK3 and MKK6 in T-cell apoptosis. EMBO Rep. 2002, 3, 785-791. [CrossRef]

134. Menon, M.B.; Gaestel, M. TPL2 meets p38MAPK: Emergence of a novel positive feedback loop in inflammation. Biochem. J. 2016, 473, 2995-2999. [CrossRef]

135. Xu, D.; Matsumoto, M.L.; MacKenzie, B.S.; Zarrin, A.A. TPL2 kinase action and control of inflammation. Pharm. Res. 2018, 129, 188-193. [CrossRef] [PubMed]

136. Liu, J.; Han, L.; Li, B.; Yang, J.; Huen, M.S.Y.; Pan, X.; Tsao, S.W.; Cheung, A.L.M. F-box only protein 31 (FBXO31) negatively regulates p38 mitogen-activated protein kinase (MAPK) signaling by mediating lysine 48-linked ubiquitination and degradation of mitogen-activated protein kinase kinase 6 (MKK6). J. Biol. Chem. 2014, 289, 21508-21518. [CrossRef] [PubMed]

137. Tanno, M.; Bassi, R. Diverse mechanisms of myocardial p38 mitogen-activated protein kinase activation: Evidence for MKK-independent activation by a TAB1-associated mechanism contributing to injury during myocardial ischemia. Circ. Res. 2003, 93, 254-261. [CrossRef] [PubMed]

138. Amantini, C.; Mosca, M.; Nabissi, M.; Lucciarini, R.; Caprodossi, S.; Arcella, A.; Giangaspero, F.; Santoni, G. Capsaicin-induced apoptosis of glioma cells is mediated by TRPV1 vanilloid receptor and requires p38 MAPK activation. J. Neurochem. 2007, 102, 977-990. [CrossRef]

139. Marrone, M.C.; Morabito, A.; Giustizieri, M.; Chiurchiù, V.; Leuti, A.; Mattioli, M.; Marinelli, S.; Riganti, L.; Lombardi, M.; Murana, E.; et al. TRPV1 channels are critical brain inflammation detectors and neuropathic pain biomarkers in mice. Nat. Commun. 2017, 8, 15292. [CrossRef]

140. Surowy, C.S.; Kym, P.R.; Reilly, R.M. Biochemical Pharmacology of TRPV1: Molecular intergrator of pain signals. In Vanilloid Receptor TRPV1 in Drug Discovery: Targeting Pain and other Pathological Disorders, 2nd ed.; Gomtsyan, A., Faltynek, C.R., Eds.; John Wiley \& Sons, Inc.: Hoboken, NJ, USA, 2010; pp. 119-120.

141. Bianco, F.; Perrotta, C.; Novellino, L.; Francolini, M.; Riganti, L.; Menna, E.; Saglietti, L.; Schuchman, E.H.; Furlan, R.; Clementi, E.; et al. Acid sphingomyelinase activity triggers microparticle release from glial cells. EMBO J. 2009, 28, 1043-1054. [CrossRef] 
142. Suter, M.R.; Berta, T.; Gao, Y.J.; Decosterd, I.; Ji, R.R. Large A-Fiber activity is required for microglial proliferation and p38 MAPK activation in the spinal cord: Different effects of resiniferatoxin and bupivacaine on spinal microglial changes after spared nerve injury. Mol. Pain 2009, 5, 53. [CrossRef]

143. Liao, H.Y.; Hsieh, C.L.; Huang, C.P. Electroacupuncture Attenuates CFA-induced Inflammatory Pain by suppressing Nav1.8 through S100B, TRPV1, Opioid, and Adenosine Pathways in Mice. Sci. Rep. 2017, 13, 42531. [CrossRef]

144. Zhou, T.T.; Wu, J.R.; Chen, Z.Y.; Liu, Z.X.; Miao, B. Effects of dexmedetomidine on P2X4Rs, p38-MAPK and BDNF in spinal microglia in rats with spared nerve injury. Brain Res. 2014, 1568, 21-30. [CrossRef]

145. Keller, A.F.; Beggs, S.; Salter, M.W.; De Koninck, Y. Transformation of the output of spinal lamina I neurons after nerve injury and microglia stimulation underlying neuropathic pain. Mol. Pain. 2007, 3, 27. [CrossRef] [PubMed]

146. Liang, J.; Deng, G.; Huang, H. The activation of BDNF reduced inflammation in a spinal cord injury model by TrkB/p38 MAPK signaling. Exp. Med. 2019, 17, 1688-1696. [CrossRef] [PubMed]

147. Cheng, C.Y.; Lin, J.G.; Su, S.Y.; Tang, N.Y.; Kao, S.T.; Hsieh, C.L. Electroacupuncture-like stimulation at Baihui and Dazhui acupoints exerts neuroprotective effects through activation of the brain-derived neurotrophic factor-mediated MEK1/2/ERK1/2/p90RSK/bad signaling pathway in mild transient focal cerebral ischemia in rats. BMC Complement Altern. Med. 2014, 14, 92. [CrossRef]

148. Schmidt, C.E.; Shastri, V.R.; Vacanti, J.P.; Langer, R. Stimulation of neurite outgrowth using an electrically conducting polymer. Proc. Natl. Acad. Sci. USA 1997, 94, 8948-8953. [CrossRef] [PubMed]

149. Jaffe, L.F.; Poo, M.M. Neurites grow faster towards the cathode than the anode in a steady field. J. Exp. Zool. 1979, 209, 115-128. [CrossRef] [PubMed]

150. Patel, N.; Poo, M.M. Orientation of neurite growth by extracellular electric fields. J. Neurosci. 1982, 2, $483-496$. [CrossRef]

151. Kerns, J.M.; Fakhouri, A.J.; Weinrib, H.P.; Freeman, J.A. Electrical stimulation of nerve regeneration in the rat: The early effects evaluated by a vibrating probe and electron microscopy. Neuroscience 1991, 40, 93-107. [CrossRef]

152. Kerns, J.M.; Lucchinetti, C. Electrical field effects on crushed nerve regeneration. Exp. Neurol. 1991, 117, 71-80. [CrossRef]

153. Todorov, A.T.; Yogev, D.; Qi, P.; Fendler, J.H.; Rodziewicz, G.S. Electric-field-induced reconnection of severed axons. Brain. Res. 1992, 582, 329-334. [CrossRef]

154. Pomeranz, B.; Campbell, J.J. Weak electric current accelerates motoneuron regeneration in the sciatic nerve of ten-month-old rats. Brain. Res. 1993, 603, 271-278. [CrossRef]

155. Chen, Y.S.; Hu, C.L.; Hsieh, C.L.; Lin, J.G.; Tsai, C.C.; Chen, T.H.; Yao, C.H. Effects of percutaneous electrical stimulation on peripheral nerve regeneration using silicone rubber chambers. J. Biomed. Mater. Res. 2001, 57, 541-549. [CrossRef]

156. Chen, Y.S.; Hsieh, C.L.; Tsai, C.C.; Chen, T.H.; Cheng, W.C.; Hu, C.L.; Yao, C.H. Increased success of peripheral nerve regeneration using silicone rubber chambers filled with an extracellular gel containing collagen, laminin and fibronectin. Biomaterials 2000, 21, 1541-1547. [CrossRef]

157. Greer, R.; Daniel, J.; Uemura, E.; Kudej, R.; Chen, Y.S.; Chung, C.H. Use of a multiple lumen cuff for nerve regeneration. Mat. Res. Soc. Symp. Proc. 1994, 331, 3-11. [CrossRef]

158. Chen, Y.S.; Miller, C.; Greer, M.H.; Quinones, M.; Greer, R.T. Development of a multiple-lumen nerve cuff utilizing growth stimulant patterns for controlled regeneration. Mat. Res. Soc. Symp. Proc. 1999, 550, 303-312. [CrossRef]

159. Zhang, R.; Lao, L.; Ren, K.; Berman, B.M. Mechanisms of acupuncture-electroacupuncture on persistent pain. Anesthesiology 2014, 120, 482-503. [CrossRef] [PubMed]

160. Silva, J.R.T.; Silva, M.L.; Prado, W.A. Analgesia induced by 2- or 100-Hz electroacupuncture in the rat tail-flick test depends on the activation of different descending pain inhibitory mechanisms. J. Pain 2011, 12, 51-60. [CrossRef] [PubMed]

161. Wang, Q.; Wang, F.; Li, X.; Yang, Q.; Li, X.; Xu, N.; Huang, Y.; Zhang, Q.; Gou, X.; Chen, S.; et al. Electroacupuncture pretreatment attenuates cerebral ischemic injury through $\alpha 7$ nicotinic acetylcholine receptor-mediated inhibition of high-mobility group box 1 release in rats. J. Neuroinflammation 2012, 9, 24. [CrossRef] 
162. Cheng, C.Y.; Lin, J.G.; Tang, N.Y.; Kao, S.T.; Hsieh, C.L. Electroacupuncture-like stimulation at the Baihui (GV20) and Dazhui (GV14) acupoints protects rats against subacute-phase cerebral ischemia-reperfusion injuries by reducing S100B-mediated neurotoxicity. PLoS ONE 2014, 9, e91426. [CrossRef]

163. Chen, H.C.; Chen, M.Y.; Hsieh, C.L.; Wu, S.Y.; Hsu, H.C.; Lin, Y.W. TRPV1 is a responding channel for acupuncture manipulation in mice peripheral and central nerve system. Cell. Physiol. Biochem. 2018, 49, 1813-1824. [CrossRef]

164. Ashwell, J. The many paths to p38 mitogen-activated protein kinase activation in the immune system. Nat. Rev. Immunol. 2006, 6, 532-540. [CrossRef]

165. Zhang, C.N.; Rahimnejad, S. Molecular characterization of p38 MAPK from blunt snout bream (Megalobrama amblycephala) and its expression after ammonia stress, and lipoplysaccaride and bacterial challenge. Fish Shellfish Immunol. 2019, 84, 848-856. [CrossRef]

166. Sreekanth, G.P.; Chuncharunee, A. SB203580 modulates p38 MAPK signaling and Dengue virus-induced liver injury by reducing MAPKAPK2, HSP27, and ATF2 phosporylation. PLoS ONE 2016, 11, e0149486. [CrossRef] [PubMed]

167. Beardmore, V.A.; Hinton, H.J. Generation and characterization of p38beta (MAPK11) gene-targeted mice. Mol. Cell Biol. 2005, 25, 10454-10464. [CrossRef] [PubMed]

168. Cheng, J.; Ji, R. Intracellular Signaling in Primary Sensory Neurons and Persistent Pain. Neurochem. Res. 2008, 33, 1970-1978. [CrossRef] [PubMed]

169. Mizukoshi, K.; Sasakia, M.; Izumia, Y.; Miuraa, M.; Watanabe, M.; Amaya, F. Activation of p38 mitogenactivated protein kinase in the dorsal root ganglion contributes to pain hypersensitivity after plantar incision. Neuroscience 2013, 234, 77-87. [CrossRef]

170. Tsuda, M. Microglia in the spinal cord and neuropathic pain. J. Diabetes Investig. 2016, 7, 17-26. [CrossRef]

171. Suzuki, N.; Hasegawa-Moriyama, M. Lidocaine attenuates the development of diabetic-induced tactile allodynia by inhibiting microglial activation. Anesth. Analg. 2011, 113, 941-946. [CrossRef]

172. Cheng, K.I.; Wang, H.C. Persistent mechanical allodynia positively correlates with an increase in activated microglia and increased P-p38 mitogen-activated protein kinase activation in streptozotocin-induced diabetic rats. Eur. J. Pain 2014, 18, 162-173. [CrossRef]

173. Hsu, H.C.; Yang, N.Y.; Lin, Y.W.; Ki, T.C.; Liu, H.J.; Hsieh, C.L. Effect of electroacupuncture on rats with chronic constriction injury-Induced neuropathic pain. Sci. World J. 2014, 2014, 129875. [CrossRef]

174. Jiang, S.W.; Lin, Y.W.; Hsieh, C.L. Electroacupuncture at Hua Tuo Jia Ji acupoints reduced neuropathic pain and increased $\mathrm{GABA}_{\mathrm{A}}$ receptors in rat spinal cord. Evid. Based Complement Altern. Med. 2018, 2018, 8041820. [CrossRef]

175. Huang, C.P.; Lin, Y.W.; Lee, D.Y.; Hsieh, C.L. Electroacupuncture relieves CCI-induced neuropathic pain involving excitatory and inhibitory neurotransmitters. Evid. Based Complement Altern. Med. 2019, 2019, 6784735. [CrossRef]

176. Lin, J.G.; Lo, M.W.; Wen, Y.R.; Hsieh, C.L.; Tsai, S.K.; Sun, W.Z. The effect of high and low frequency electroacupuncture in pain after lower abdominal surgery. Pain 2002, 99, 509-514. [CrossRef]

177. Wang, B.; Tang, J.; White, P.F.; Naruse, R.; Sloninsky, A.; Kariger, R.; Gold, J.; Wender, R.H. Effect of the intensity of transcutaneous acupoint electrical stimulation on the postoperative analgesic requirement. Anesth. Analg. 1997, 85, 406-413. [PubMed]

178. Chen, W.H.; Hsieh, C.L.; Huang, C.P.; Lin, T.J.; Tzen, J.T.C.; Ho, T.Y.; Lin, Y.W. Acid-sensing ion channel 3 mediates peripheral anti-hyperalgesia effects of acupuncture in mice inflammatory pain. J. Biomed. Sci. 2011, 18, 82. [CrossRef] [PubMed]

179. Chen, W.H.; Tzen, J.T.C.; Hsieh, C.L.; Chen, Y.H.; Lin, T.J.; Chen, S.Y.; Lin, Y.W. Attenuation of TRPV1 and TRPV4 expression and function in mouse inflammatory pain models using electroacupuncture. J. Biomed. Sci. 2012, 2012. [CrossRef]

180. Huang, C.P.; Chen, H.N.; Su, H.L.; Hsieh, C.L.; Chen, W.H.; Lai, Z.R.; Lin, Y.W. Electroacupuncture reduces carrageenan- and CFA-induced inflammatory pain accompanied by changing the expression of Nav1.7 and Nav1.8, rather than Nav1.9, in mice dorsal root ganglia. Evid. Based Complement Altern. Med. 2013, 2013, 312184. [CrossRef]

181. Wu, S.Y.; Chen, W.H.; Hsueh, C.H.; Lin, Y.W. Abundant expression and functional participation of TRPV1 at Zusanli acupoint (ST36) in mice: Mechanosensitive TRPV1 as an acupuncture-responding channel. BMC Complement Altern. Med. 2014, 14, 96. [CrossRef] 
182. Lu, K.W.; Hsu, C.K.; Hsieh, C.L.; Yang, J.; Lin, Y.W. Probing the effects and mechanisms of electroacupuncture at ipsilateral or contralateral ST36-ST37 acupoints on CFA-induced inflammatory pain. Sci. Rep. 2016, 24, 22123. [CrossRef]

183. Liao, H.Y.; Hsieh, C.L.; Huang, C.P.; Lin, Y.W. Electroacupuncture attenuates induction of inflammatory pain by regulating opioid and adenosine pathways in mice. Sci. Rep. 2017, 7, 15679. [CrossRef]

184. Yang, J.; Hsieh, C.L.; Lin, Y.W. Role of transient receptor potential vanilloid 1 in electroacupuncture analgesia on chronic inflammatory pain in mice. Biomed Res. Int. 2017, 2017, 5068347. [CrossRef]

185. Yen, C.M.; Wu, T.C.; Hsieh, C.L.; Huang, Y.W.; Lin, Y.W. Distal electroacupuncture at the LI4 acupoint reduces CFA-induced inflammatory pain via the brain TRPV1 signaling pathway. Int. J. Mol. Sci. 2019, 20, 4471. [CrossRef]

186. Hsu, H.C.; Hsieh, C.L.; Wu, S.Y.; Lin, Y.W. Toll-like receptor 2 plays an essential role in electroacupuncture analgesia in a mouse model of inflammatory pain. Acupunct. Med. 2019, 37, 356-364. [CrossRef] [PubMed]

187. Yang, C.P.; Hsieh, C.L.; Wang, N.H.; Li, T.C.; Hwang, K.L.; Yu, S.C.; Chang, M.H. Acupuncture in patients with carpal tunnel syndrome: A randomized controlled trial. Clin. J. Pain. 2009, 25, 327-333. [CrossRef] [PubMed]

188. Yang, C.P.; Wang, N.H.; Li, T.C.; Hsieh, C.L.; Chang, H.H.; Hwang, K.L.; Ko, W.S.; Chang, M.H. A randomized clinical trial of acupuncture versus oral steroids for carpal tunnel syndrome: A long-term follow-up. J. Pain 2011, 12, 272-279. [CrossRef] [PubMed]

189. Yang, C.P.; Chang, M.H.; Liu, P.E.; Li, T.C.; Hsieh, C.L.; Hwang, K.L.; Chang, H.H. Acupuncture versus topiramate in chronic migraine prophylaxis: A randomized clinical trial. Cephalalgia 2011, 31, 1510-1521. [CrossRef]

190. Walder, R.Y.; Rasmussen, L.A.; Rainier, J.D.; Light, A.R.; Wemmie, J.A.; Sluka, K.A. ASIC1 and ASIC3 play different roles in the development of hyperalgesia after inflammatory muscle injury. J. Pain 2010, 11, 210-218. [CrossRef]

191. Black, J.A.; Liu, S.; Tanaka, M.; Cummins, T.R.; Waxman, S.G. Changes in the expression of tetrodotoxinsensitive sodium channels within dorsal root ganglia neurons in inflammatory pain. Pain 2004, 108, $237-247$. [CrossRef]

192. Yu, L.; Yang, F.; Luo, H.; Liu, F.Y.; Han, J.S.; Xing, G.G.; Wan, Y. The role of TRPV1 in different subtypes of dorsal root ganglion neurons in rat chronic inflammatory nociception induced by complete Freund's adjuvant. Mol. Pain 2008, 4, 61. [CrossRef]

193. Goldman, N.; Chen, M.; Fujita, T.; Xu, Q.; Peng, W.; Liu, W.; Jensen, T.; Pei, Y.; Wang, F.; Han, X.; et al. Adenosine A1 receptors mediate local anti-nociceptive effects of acupuncture. Nat. Neurosci. 2010, 13, 883-888. [CrossRef]

194. Silberstein, S.D. Migraine pathophysiology and its clinical implications. Cephalalgia 2004, 24 (Suppl. 2), 2-7. [CrossRef]

195. Burstein, R.; Noseda, R.; Borsook, D. Migraine: Multiple processes, complex pathophysiology. J. Neurosci. 2015, 35, 6619-6629. [CrossRef]

196. Sabino, G.S.; Santos, C.M.; Francischi, J.N.; de Resende, M.A. Release of endogenous opioids following transcutaneous electric nerve stimulation in an experimental model of acute inflammatory pain. J. Pain 2008, 9, 157-163. [CrossRef] [PubMed]

197. King, E.W.; Audette, K.; Athman, G.A.; Nguyen, H.O.; Sluka, K.A.; Fairbanks, C.A. Transcutaneous electrical nerve stimulation activates peripherally located alpha-2A adrenergic receptors. Pain 2005, 115, 364-373. [CrossRef] [PubMed]

198. Ainsworth, L.; Budelier, K.; Clinesmith, M.; Fiedler, A.; Landstrom, R.; Leeper, B.J.; Moeller, L.; Mutch, S.; O'Dell., K.; Ross, J.; et al. Transcutaneous electrical nerve stimulation (TENS) reduces chronic hyperalgesia induced by muscle inflammation. Pain 2006, 120, 182-187. [CrossRef]

199. Sekido, R.; Ishimaru, K.; Sakita, M. Differences of electroacupuncture-induced analgesic effect in normal and inflammatory conditions in rats. Am. J. Chin. Med. 2003, 31, 955-965. [CrossRef] [PubMed]

200. Zhao, W.; Liu, M.; Kirkwood, K.L. p38alpha stabilizes interleukin-6 mRNA via multiple AU-rich elements. J. Biol. Chem. 2008, 283, 1778-1785. [CrossRef] [PubMed]

201. Tudor, C.; Marchese, F.P. p38 mitogen-activated protein kinase inhibits tristetraprolin-directed decay of the mRNA of the anti-inflammatory cytokine interleukin-10. FEBS Lett. 2009, 583, 1933-1938. [CrossRef] 
202. Berger, C.; von Kummer, R. Does NO regulate the cerebral blood flow response in hypoxia? Acta Neurol. Scand. 2009, 97, 118-125. [CrossRef]

203. Cheng, C.Y.; Lin, J.G.; Tang, N.Y.; Kao, S.T.; Hsieh, C.L. Electroacupuncture at different frequencies (5Hz and $25 \mathrm{~Hz}$ ) ameliorates cerebral ischemia-reperfusion injury in rats: Possible involvement of p38 MAPK-mediated anti-apoptotic signaling pathways. BMC Complement Altern. Med. 2015, 15, 241. [CrossRef]

204. Armstrong, S.C.; Delacey, M.; Ganote, C.E. Phosphorylation state of hsp27 and p38 MAPK during preconditioning and protein phosphatase inhibitor protection of rabbit cardiomyocytes. J. Mol. Cell Cardiol. 1999, 31, 555-567. [CrossRef]

205. Marais, E.; Genade, S.; Salie, R.; Huisamen, B.; Maritz, S.; Moolman, J.A.; Lochner, A. The temporal relationship between $\mathrm{p} 38$ MAPK and HSP 27 activation in ischaemic and pharmacological preconditioning. Basic Res. Cardiol. 2005, 100, 35-47. [CrossRef]

206. Fan, W.; Gao, X.K. Hsp70 interacts with mitogen-activated protein kinase (MAPK)-activated protein kinase 2 to regulate p38MAPK stability and myoblast differentiation during skeletal muscle regeneration. Mol. Cell Biol. 2018, 38. [CrossRef] [PubMed]

207. Chang, Q.Y.; Lin, Y.W.; Hsieh, C.L. Acupuncture and neuroregeneration in ischemic stroke. Neural Regen. Res. 2018, 13, 573-583. [CrossRef] [PubMed]

208. Xu, H.; Sun, H.; Chen, S.H.; Zhang, Y.M.; Piao, Y.L.; Gao, Y. Effects of acupuncture at Baihui (DU20) and Zusanli (ST36) on the expression of heat shock protein 70 and tumor necrosis factor $\alpha$ in the peripheral serum of cerebral ischemia-reperfusion-injured rats. Chin. J. Integr. Med. 2014, 20, 369-374. [CrossRef]

209. Dayalan Naidu, S.; Sutherland, C.; Zhang, Y.; Risco, A.; de la Vega, L.; Caunt, C.J.; Hastie, C.J.; Lamont, D.J.; Torrente, L.; Chowdhry, S.; et al. Heat Shock Factor 1 is a substrate for p38 mitogen-activated protein kinase. J. Mol. Cell Biol. 2016, 36, 2403-2417. [CrossRef] [PubMed]

210. Jin, X.; Qiao, A.; Moskophidis, D.; Mivechi, N.F. Modulation of Heat Shock Factor 1 Activity through Silencing of Ser303/Ser307 Phosphorylation Supports a Metabolic Program Leading to Age-Related Obesity and Insulin Resistance. Mol. Cell Biol. 2018, 38, e00095-18. [CrossRef] [PubMed]

211. Ni, H.; Wang, X.S. MAPKAPK5, a novel mitogen-activated protein kinase (MAPK)-activated protein kinase, is a substrate of the extracellular-regulated kinase (ERK) and p38 kinase. Biochem. Biophys. Res. Comm. 1998, 243, 492-496. [CrossRef]

212. Sahadevan, P.; Allen, B.G. MK5: A novel regulator of cardiac fibroblast function? Iubmb Life 2017, 69, 785-794. [CrossRef]

213. Shiryaev, A.; Moens, U. Mitogen-activated protein kinase p38 and MK2, MK3 and MK5: Ménage à trois or ménage à quatre. Cell Signal. 2010, 22, 1185-1192. [CrossRef]

214. Liu, C.H.; Lin, Y.W.; Tang, N.Y.; Liu, H.J.; Hsieh, C.L. Neuroprotective Effect of Uncaria rhynchophylla in kainic acid-induced epileptic seizures by modulating hippocampal mossy fiber sprouting, neuron survival, astrocyte proliferation, and S100B expression. Evid. Based Complement Altern. Med. 2012, 2012, 194790. [CrossRef]

215. Kim, S.T.; Jeon, S.; Park, H.J.; Hong, M.S.; Jeong, W.B.; Kim, J.H.; Kim, Y.; Lee, H.J.; Park, H.J.; Chung, J.H. Acupuncture inhibits kainic acid-induced hippocampal cell death in mice. J. Physiol. Sci. 2008, 58, 31-38. [CrossRef]

216. Kim, S.T.; Doo, A.R.; Kim, S.N.; Kim, S.Y.; Kim, Y.Y.; Kim, J.H.; Lee, H.; Yin, C.S.; Park, H.J. Acupuncture suppresses kainic acid-induced neuronal death and inflammatory events in mouse hippocampus. J. Physiol. Sci. 2012, 62, 377-383. [CrossRef] [PubMed]

217. Bae, C.H.; Kim, D.S.; Jun, Y.L.; Kwon, S.; Park, H.J.; Hahm, D.H.; Lee, H.; Kim, S.T. Proteomic analysis of the effect of acupuncture on the suppression of kainic acid-induced neuronal destruction in mouse hippocampus. Evid. Based Complement Altern. Med. 2013, 2013, 436315. [CrossRef] [PubMed]

218. Liu, C.H.; Lin, Y.W.; Hsu, H.C.; Liu, H.J.; Lin, W.J.; Hsieh, C.L. Electroacupuncture at ST36-ST37 and at ear ameliorates hippocampal mossy fiber sprouting in kainic acid-induced epileptic seizure rats. Biomed Res. Int. 2014, 2014, 756019. [CrossRef] [PubMed]

219. Hsu, H.C.; Tang, N.Y.; Liu, C.H.; Hsieh, C.L. Antiepileptic Effect of Uncaria rhynchophylla and Rhynchophylline involved in the initiation of c-Jun N-terminal kinase phosphorylation of MAPK signal pathways in acute seizures of kainic acid-treated rats. Evid. Based Complement Altern. Med. 2013, 2013, 961289. [CrossRef] [PubMed] 
220. Lin, Y.W.; Hsieh, C.L. Auricular electroacupuncture reduced inflammation-related epilepsy accompanied by altered TRPA1, $\mathrm{pPKC} \alpha, \mathrm{pPKC} \varepsilon$, and $\mathrm{pERk1} / 2$ signaling pathways in kainic acid-treated rats. Mediat. Inflamm. 2014, 2014, 493480. [CrossRef]

221. Liao, E.T.; Tang, N.Y.; Lin, Y.W.; Hsieh, C.L. Long-term electrical stimulation at ear and electro-acupuncture at ST36-ST37 attenuated COX-2 in the CA1 of hippocampus in kainic acid-induced epileptic seizure rats. Sci. Rep. 2017, 7, 472. [CrossRef]

222. Inprasit, C.; Lin, Y.W.; Huang, C.P.; Wu, S.Y.; Hsieh, C.L. Targeting TRPV1 to relieve motion sickness symptoms in mice by electroacupuncture and gene deletion. Sci. Rep. 2018, 8, 10365. [CrossRef] [PubMed]

223. Maione, S.; Cristino, L.; Migliozzi, A.; Georgiou, A.; Starowicz, K.; Salt, T.; Marzo, V. TRPV1 channels control synaptic plasticity in the developing superior colliculus. J. Physiol. 2009, 587, 2521-2535. [CrossRef]

224. Puig, B.; Gomez-Isla, T. Expression of stress-activated kinases c-Jun N-terminal kinase (SAPK/JNK-P) and p38 kinase (p38-P), and tau hyperphosphorylation in neurites surrounding betaA plaques in APP Tg2576 mice. Neuropathol. Appl. Neurobiol. 2004, 30, 491-502. [CrossRef]

225. Risco, A.; Cuenda, A. New Insights into the p38 $\gamma$ and p38 8 MAPK Pathways. J. Signal Transduct. 2012, 2012, 520289. [CrossRef]

226. Escós, A.; Risco, A. p38 $\gamma$ and p388 Mitogen Activated Protein Kinases (MAPKs), New Stars in the MAPK Galaxy. Front. Cell Dev. Biol. 2016, 4, 31. [CrossRef]

227. Maphis, N.; Jiang, S. Selective suppression of the alpha isoform of p38 MAPK rescues late-stage tau pathology. Alzheimers Res. 2016, 8, 54. [CrossRef] [PubMed]

228. Lin, Y.W.; Hsieh, C.L. Electroacupuncture at Baihui acupoint (GV20) reverses behavior deficit and long-term potentiation through N-methyl-d-aspartate and transient receptor potential vanilloid subtype 1 receptors in middle cerebral artery occlusion rats. J. Integr. Neurosci. 2010, 9, 269-282. [CrossRef]

229. Dong, W.; Guo, W.; Zheng, X.; Wang, F.; Chen, Y.; Zhang, W.; Shi, H. Electroacupuncture improves cognitive deficits associated with AMPK activation in SAMP8 mice. Metab. Brain Dis. 2015, 30, 777-784. [CrossRef] [PubMed]

230. Song, J.J.; Lee, Y.J. Role of the ASK1-SEK1-JNK1- HIPK1 signal in Daxx trafficking and ASK1 oligomerization. J. Biol. Chem. 2003, 278, 47245-47252. [CrossRef] [PubMed]

231. Chang, H.Y.; Nishitoh, H.; Yang, X.; Ichijo, H.; Baltimore, D. Activation of apoptosis signal-regulating kinase 1 (ASK1) by the adapter protein Daxx. Science 1988, 281, 1860-1863. [CrossRef] [PubMed]

232. Akterin, S.; Cowburn, R.F.; Miranda-Vizuete, A.; Jimenez, A.; Bogdanovic, N.; Winblad, B.; Cedazo-Minguez, A. Involvement of glutaredoxin-1 and thioredoxin-1 in amyloid toxicity and Alzheimer's disease. Cell Death Differ. 2006, 13, 1454-1465. [CrossRef]

233. Takahashi-Niki, K.; Niki, T.; Taira, T.; Iguchi-Ariga, S.M.M.; Ariga, H. Reduced anti-oxidative stress activities of DJ-1 mutants found in Parkinson's disease patients. Biochem. Biophys. Res. Commun. 2004, 320, 389-397. [CrossRef]

234. Junn, E.; Taniguchi, H.; Jeong, B.S.; Zhao, X.; Ichijo, H.; Mouradian, M.M. Interaction of DJ-1 with Daxx inhibits apoptosis signal-regulating kinase 1 activity and cell death. Proc. Natl. Acad. Sci. USA 2005, 102, 9691-9696. [CrossRef]

235. Tang, J.; Liu, J.; Li, X.; Zhong, Y.; Zhong, T.; Liu, Y.; Wang, J.H.; Jiang, Y. PRAK Interacts with DJ-1 and prevents oxidative stress-induced cell death. Oxid. Med. Cell. Longev. 2014, 735618. [CrossRef]

236. Karunakaran, S.; Diwakar, L. Activation of apoptosis signal regulating kinase 1 (ASK1) and translocation of death-associated protein, Daxx, in substantia nigra pars compacta in a mouse model of Parkinson's disease: Protection by alpha-lipoic acid. FASEB J. 2007, 21, 2226-2236. [CrossRef] [PubMed]

237. Lu, K.W.; Yang, J.; Hsieh, C.L.; Hsu, Y.C.; Lin, Y.W. Electroacupuncture restores spatial learning and downregulates phosphorylated N-methyl-D-aspartate receptors in a mouse model of Parkinson's disease. Acupunct. Med. 2017, 35, 133-141. [CrossRef] [PubMed]

238. Lin, J.G.; Hsieh, C.L.; Lin, Y.W. Analgesic effect of electroacupuncture in a mouse fibromyalgia model: Roles of TRPV1, TRPV4, and pERK. PLoS ONE 2015, 10, e0128037. [CrossRef] [PubMed]

239. Lu, K.W.; Hsieh, C.L.; Yang, J.; Lin, Y.W. Effects of electroacupuncture in a mouse model of fibromyalgia: Role of N-methyl-D-aspartate receptors and related mechanisms. Acupunct. Med. 2017, 35, 59-68. [CrossRef]

(C) 2020 by the authors. Licensee MDPI, Basel, Switzerland. This article is an open access article distributed under the terms and conditions of the Creative Commons Attribution (CC BY) license (http://creativecommons.org/licenses/by/4.0/). 